\title{
Review \\ Uncommon Terpenoids from Salvia Species: Chemistry, Biosynthesis and Biological Activities
}

\author{
Salar Hafez Ghoran 1,2,*(D), Fatemeh Taktaz ${ }^{3}$, Ali Akbar Mozafari ${ }^{2}$, Murat Tunçtürk ${ }^{4}$ (D), Nazim Sekeroglu ${ }^{5}$ (D) \\ and Anake Kijjoa $6, *$ (D)
}

1 Phytochemistry Research Center, Shahid Beheshti University of Medical Sciences, Tehran, Iran

2 Medicinal Plant Breeding \& Development Research Institute, University of Kurdistan,

Sanandaj 66177-15175, Iran; a.mozafari@uok.ac.ir

3 Department of Biology, Faculty of Sciences, University of Hakim Sabzevari, Sabzevar 96179-76487, Iran; f.taktaz@gmail.com

4 Field Crop Department, Agricultural Faculty, Van Yuzuncu Yil University, Van 65090, Turkey; murattuncturk@yyu.edu.tr

5 Phytotherapy, Medicinal and Aromatic Plants Application \& Research Center and Biology Department, Faculty of Arts and Science, Gaziantep University, Gaziantep 27310, Turkey; nsekeroglu@gmail.com

6 ICBAS-Instituto de Ciências Biomédicas Abel Salazar and CIIMAR, Universidade do Porto, Rua de Jorge Viterbo Ferreira, 228, 4050-313 Porto, Portugal

* Correspondence: s_hafezghoran@yahoo.com (S.H.G.); ankijjoa@icbas.up.pt (A.K.); Tel.: +98-9144425047 (S.H.G.); +351-962712474 (A.K.)

check for updates

Citation: Hafez Ghoran, S.; Taktaz, F.; Mozafari, A.A.; Tunçtürk, M.; Sekeroglu, N.; Kijjoa, A. Uncommon Terpenoids from Salvia Species: Chemistry, Biosynthesis and Biological Activities. Molecules 2022, 27, 1128. https://doi.org/10.3390/ molecules27031128

Academic Editor: Stefano Dall'Acqua

Received: 29 January 2022

Accepted: 6 February 2022

Published: 8 February 2022

Publisher's Note: MDPI stays neutral with regard to jurisdictional claims in published maps and institutional affiliations.

Copyright: (c) 2022 by the authors Licensee MDPI, Basel, Switzerland. This article is an open access article distributed under the terms and conditions of the Creative Commons Attribution (CC BY) license (https:// creativecommons.org/licenses/by/ $4.0 /)$.
Abstract: The search for new bioactive compounds from plant sources has been and continues to be one of the most important fields of research in drug discovery. However, Natural Products research has continuously evolved, and more and more has gained a multidisciplinary character. Despite new developments of methodologies and concepts, one intriguing aspect still persists, i.e., different species belonging to the same genus can produce different secondary metabolites, whereas taxonomically different genera can produce the same compounds. The genus Salvia L. (Family Lamiaceae) comprises myriad distinct medicinal herbs used in traditional medicine worldwide that show different pharmacological activities due to the presence of a variety of interesting specialized metabolites, including mono-, sesqui-, di-, sester-, tri-, tetra-, and higher terpenoids as well as phenylpropanoids, phenolic acid derivatives, lignans, flavonoids, and alkaloids. We herein summarize the research progress on some uncommon terpenoids, isolated from members of the genus Salvia, which are well recognized for their potential pharmacological activities. This review also provides a current knowledge on the biosynthesis and occurrence of some interesting phytochemicals from Salvia species, viz. $\mathrm{C}_{23}$-terpenoids, sesterterpenoids $\left(\mathrm{C}_{25}\right)$, dammarane triterpenoids $\left(\mathrm{C}_{30}\right)$, and uncommon triterpenoids $\left(\mathrm{C}_{20}+\mathrm{C}_{10}\right)$. The study was carried out by searching various scientific databases, including Elsevier, ACS publications, Taylor and Francis, Wiley Online Library, MDPI, Springer, Thieme, and ProQuest. Therefore, 106 uncommon terpenoids were identified and summarized. Some of these compounds possessed a variety of pharmacological properties, such as antibacterial, antiviral, antiparasitic, cytotoxic and tubulin tyrosine ligase inhibitory activities. Due to the lack of pharmacological information for the presented compounds gathered from previous studies, biological investigation of these compounds should be reinvestigated.

Keywords: Salvia L.; Lamiaceae; sesterterpenoids; dammarane-type triterpenoids; uncommon triterpenoids; cytotoxicity; antiparasitic activity

\section{Introduction}

The genus Salvia L., commonly known as "sage", is one of the largest genera of the family Lamiaceae/Labiatae (subfamily Nepetoideae, tribe Mentheae) comprising over 
1000 species worldwide. However, only approximately 150 of them have been investigated [1]. Sage plants are an herbaceous, aromatic and shrubby perennial and are distributed mainly in the Mediterranean, Middle East, the Pacific islands, tropical Africa, and America [2]. Most significant Salvia species are found in Mexico (ca. 300, which is the largest number) followed by Turkey (with more than 90 and half of which are indigenous) [3], China (ca. 84) [4], Iran (ca. 62) [5], and Africa (ca. 30) [6]. This genus also is rich in medicinal plants with recognized therapeutic properties for treatment of many ailments [6,7].

The most well-recognized species such as S. officinalis (common sage), S. miltiorrhiza (red sage; Danshen in Chinese), S. lavandulifolia (Spanish sage), S. sclarea (clary sage), S. hispanica (chia), S. triloba, and S. mirzayanii (a potent anti-diabetic plant in Iran) have been used extensively as medicinal plants in folk medicine in several countries, and some species are cultivated worldwide for culinary purposes [8,9]. Moreover, some species of Salvia also exhibit interesting pharmacological activities such as anti-Alzheimer's and cognitive-enhancing (S. miltiorrhiza [10], S. officinalis [11], and S. lavandulaefolia [12]); antidepressant (S. sclarea [13] and S. elegans [14]); cardiovascular (S. hispanica L. [15]); antihyperglycemic/hyperlipidemic (S. amarissima Ortega [16], S. splendens (scarlet sage) [17], and S. hydrangea [18]); hypotensive (S. cinnabarina [19]); anti-inflammatory (S. circinnata Cav. [20], S. rosmarinus Spenn. [21], S. plebeian [22], and S. verbenaca L. [23]); antioxidant (S. dracocephaloides Boiss. [24], S. multicaulis [25], S. pilifera [26], S. elegans, S. gerggii, and S. officinalis [27]); cytotoxic/anti-proliferative (S. fruticosa Mill [28], S. macrosiphon Boiss. [29], S. tebesana Bunge [30], and S. atropatana Bunge [31]); antiprotozoal (S. clinopodioides [32], S. uliginosa [33], and S. austriaca [34]); antifungal (S. macrochlamys, S. recognita [35], and S. desoleana Atzei \& Picci [36]); antiviral (S. plebeia R. Br. [37], S. wiedemannii Boiss. [38], S. officinalis [39], S. dentata Aiton, S. scabra Thunb. [40]); and antimicrobial (S. euphratica Montbret, S. kornenburgii Rech. f. [41], and S. chamaedryoides [42]).

A great diversity of Salvia plants, combined with their phytochemical richness, has attracted attention of researchers to discover new pharmacologically active compounds with novel scaffolds. Most significantly, until now, a small number of uncommon terpenoid metabolites have been reported from Salvia species, while mono-, sesqui-, di-(abietanes, clerodanes, labdanes, pimaranes, and ent-kauranes), sester-, tri- (oleananes, ursanes, and lupanes) terpenoids, phenylpropanoids, phenolic acids, and flavonoids have been frequently reported [2].

Salvia species are more likely to provide many lead structures that can be exploited as templates for the construction of a variety of compounds with enhanced pharmacological properties and less toxicity. The following subsections of this review will cover $\mathrm{C}_{23}$-terpenoids, sesterterpenoids $\left(C_{25}\right)$, dammarane-type triterpenoids $\left(C_{30}\right)$, and uncommon triterpenoids $\left(\mathrm{C}_{20}+\mathrm{C}_{10}\right)$, discussing their structural features as well as biological/pharmacological activities where available.

According to our literature search, there are no comprehensive reviews on uncommon terpenoids from the genus Salvia so far. Hence, we present in this review some complementary aspects and an update of the previous reviews $[2,43,44]$, aiming to provide the latest information on their structural diversity and biological activities. The databases used to search for the keywords and terpenoid compounds were PubMed, Web of Science, Scopus, and Google Scholar.

\section{2. $\mathrm{C}_{23}$-Terpenoids}

Apianane terpenes represent the unprecedented $\mathrm{C}_{23}$ basic carbon skeleton with a 6/6/5/5-ring system that originated from tetraprenyl terpenoids, first isolated from the aerial parts of $S$. apiana Jeps (also known as white sage). Phytochemical investigation of S. apiana furnished 14-hydroxy-7-methoxy-11,16-diketo-apian-8-en-(22,6)-olide (1) and 7-methoxy-11,16-diketo-apian-8,14-dien-(22,6)-olide (2) (Figure 1). Luis et al. postulated that the condensation product of 7-methoxyrosmanol with acetoacetyl coenzyme A (CoA) acts as a precursor in the biosynthetic pathway of $\mathbf{1}$ [45]. Upon reexamination of the same extract, the same research group was able to isolate and identify a new $\mathrm{C}_{23}$-hassanane 
terpenoid that contains a 6/6/8-ring system, 13,14-dioxo-11-hydroxy-7-methoxy-hassane8,11,15-trien-(22,6)-olide (3) (Figure 1). The most interesting ${ }^{1} \mathrm{H}$ NMR feature of 3 is the presence of an uncommonly high chemical shift value of a hydroxyl group on C-11 at $\delta_{\mathrm{H}}$ 17.03. Using this information along with the computational PCMODEL program, it was possible to confirm the presence of a hydrogen bond between the carbonyl group (C-22) and $\mathrm{OH}-11[46]$.<smiles>CCOC(=O)CC(C)=O</smiles>

7-hydroxyrosmanol

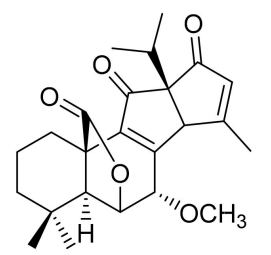

2<smiles>CC(C)O</smiles>

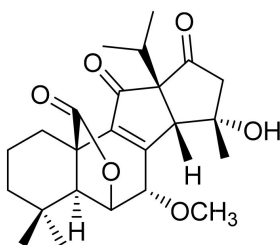

1

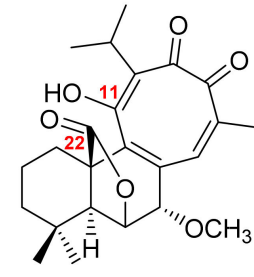

3
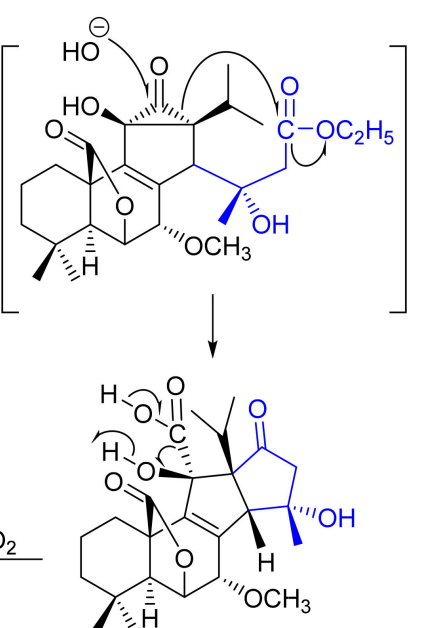

[O]

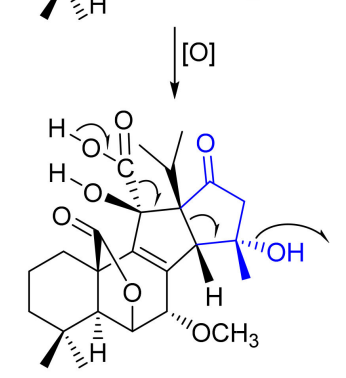

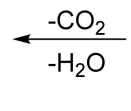

$\overline{\bar{H}}$

Figure 1. Proposed biosynthetic pathway of 1-3.

Repeated chromatographic purification of a dichloromethane $\left(\mathrm{CH}_{2} \mathrm{Cl}_{2}\right)$ extract of the leaves of $S$. officinalis resulted in the isolation of three apianane terpenes, viz. rel$(5 S, 6 S, 7 S, 10 R, 12 S, 13 R)$-7-hydroxyapiana-8,14-diene-11,16-dion-(22,6)-olide (4), rel-(5S,6S,7R, $10 R, 12 S, 13 R)-7$-hydroxyapiana-8,14-diene-11,16-dion-(22,6)-olide (5), rel-(5S,6S,7S,10R,12R, 13S)-7-hydroxyapiana-8,14-diene-11,16-dion-(22,6)-olide (6) (Figure 2), together with 15 previously reported compounds. The relative configurations of 4-6 were confirmed by a Nuclear Overhauser Effect Spectroscopy (NOESY) from which the presence or absence of correlations from $\mathrm{H}-5$ to $\mathrm{H}-7, \mathrm{H}-7$ to $\mathrm{H}-13, \mathrm{H}-13$ to 12 -isopropyl group was used to determine the $\alpha$-and/or $\beta$-configurations [47].

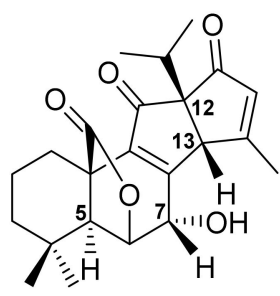

4

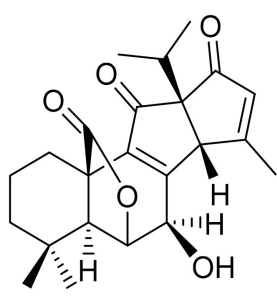

5

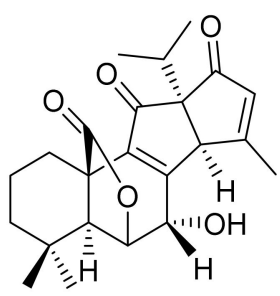

6

Figure 2. Structures of 4-6. 
Further $\mathrm{C}_{23}$-terpenoids with a 6/6/7-ring system, przewalskin $\mathrm{A}$ (7) and its keto analog (8), were isolated from the acetone extract of the aerial parts of S. przewalskii Maxim, collected in Shanggelila, Yunnan Province, China. ROESY correlations from Me-22 to H-23 revealed that the hydroxyl group on $\mathrm{C}-23$ in 7 was $\alpha$-oriented. A putative biosynthetic pathway was also proposed to proceed through a condensation of a normal $o$-quinone diterpene with acetoacetyl-CoA, followed by an intramolecular aldol and oxidation reactions (Figure 3) [48]. Unlike $o$-quinone abietane diterpenes, which exhibited antitumor activity [49], 7 and 8 showed no cytotoxic activity against HL-60 (promyelocytic leukemia), K562 (human immortalized myelogenous leukemia), OVCA-2780 (ovarian), A549 (lung), and HepG-2 (liver) cancer cell lines [48].

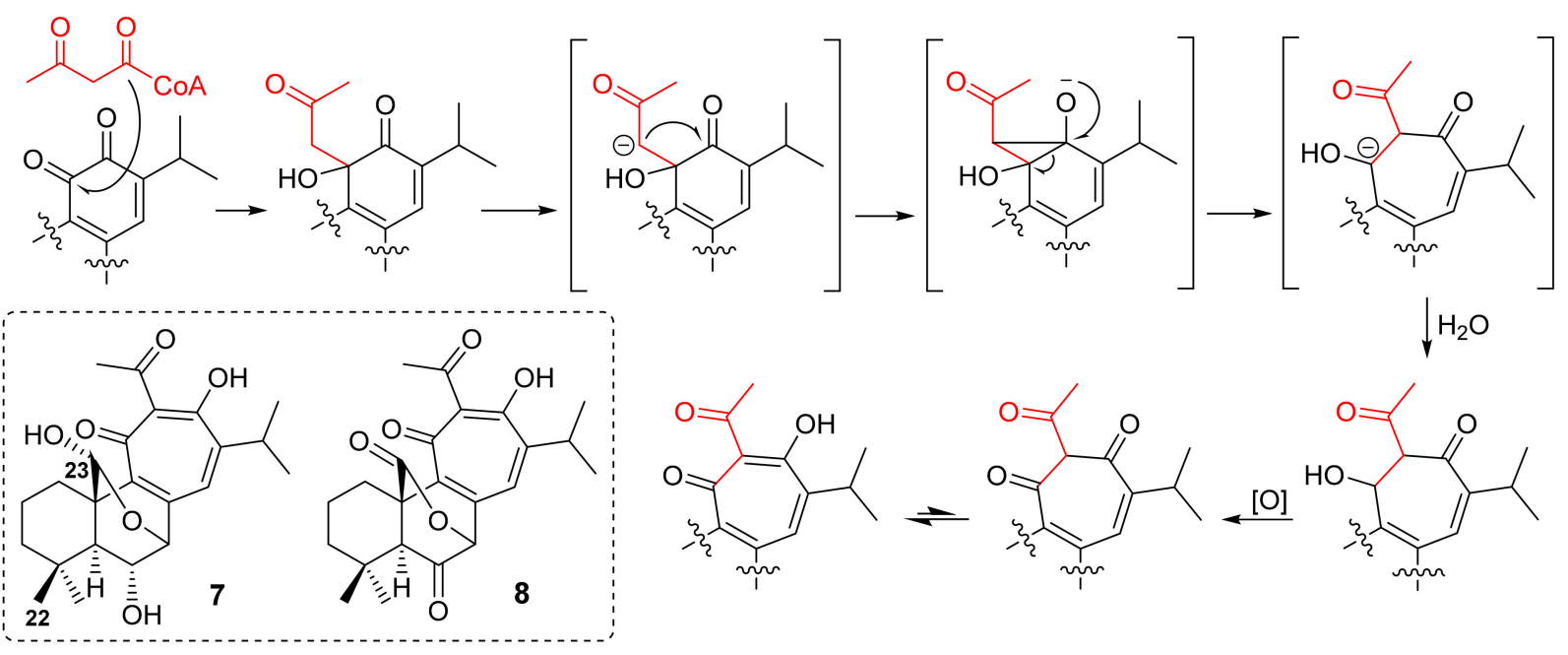

Figure 3. Proposed biosynthetic pathway for 7 and 8.

\section{Sesterterpenoids}

Sesterterpenes $\left(\mathrm{C}_{25}\right)$ are a class of terpenoid compounds that have been frequently reported from bacteria, fungi, lichens, insects, marine invertebrates (particularly marine sponges), and some higher plant families such as Asteraceae, Lamiaceae, Lobariaceae, Gentianaceae, and Pteridaceae. Sesterterpenoids are among the most interesting classes of specialized metabolites since they possess relevant biological and pharmacological activities [50]. Sesterterpenoids reported from plants of the genus Salvia possess a prenyllabdane skeleton (Figure 4) [51], all containing a $\gamma$-lactone ring. Accordingly, these specialized metabolites are divided into three different subgroups.

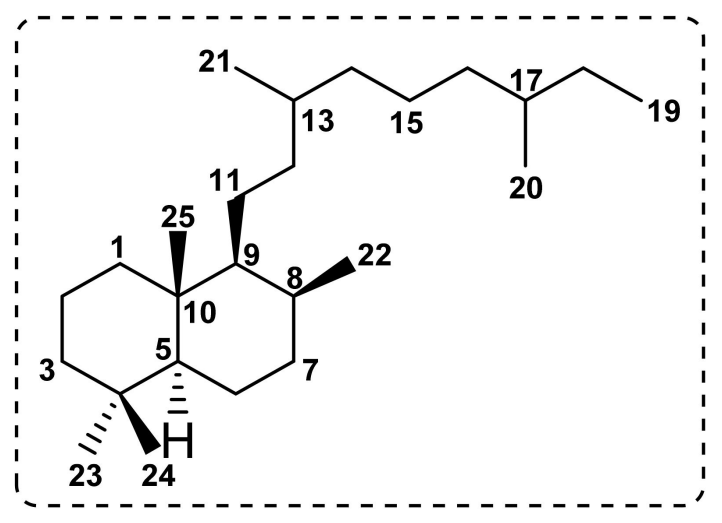

Figure 4. A carbon skeleton of sesterterpenoids from plants of the genus Salvia. 


\subsection{Bicyclic Sesterterpenoids}

A literature search on Salvia plants revealed that only eight species biosynthesize $\gamma$-lactone-containing bicyclic sesterterpenes. They are S. hypoleuca, S. syriaca, S. sahendica, S. mirzayanii, S. palaestina, S. lachnocalyx, S. dominica and S. tingitana, half of which are endemic to Iran. A plausible biosynthetic pathway is shown in Figure 5. As an example of this type of sesterterpenes, we can infer the following specialized metabolites with the increasing oxidation state of $\mathrm{C}-23$ from $\mathrm{CH}_{3}$ to $\mathrm{CH}_{2} \mathrm{OH}, \mathrm{CHO}, \mathrm{COOH}, \mathrm{COOMe}$ and the lactone ring between C-6 and C-23.

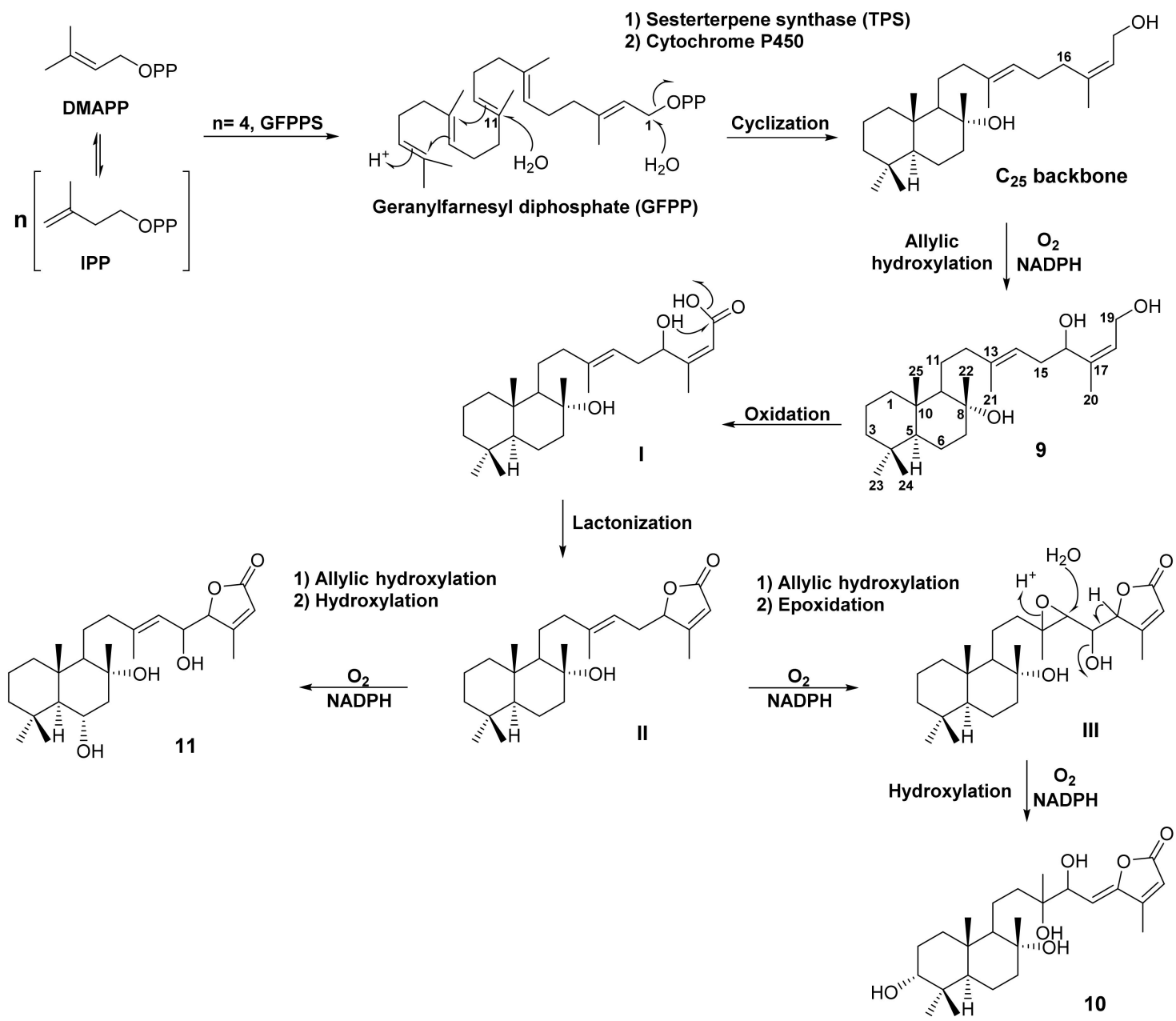

Figure 5. Structures of 9-11 and their proposed biosynthetic pathway.

\subsubsection{Bicyclic Sesterterpene Lactones Containing C-23 Methyl Group}

Purification of the $n$-hexane-insoluble portion of a $\mathrm{CH}_{2} \mathrm{Cl}_{2}$ extract of fresh aerial parts of S. tingitana, obtained in San Remo, Italy, by several chromatographic techniques including column chromatography (CC) of silica gel and Sephadex LH-20, and semipreparative high performance liquid chromatography (HPLC), resulted in the isolation of (13E)-labd-13(14),17(18)-dien-8 $\alpha, 16,19$-triol (9) (Figure 5). The structure of 9 was elucidated by high-resolution electrospray ionization mass spectrometry (HRESIMS) and 1D and 2D NMR spectral analysis, while its relative configuration was established by NOESY correlations from $\mathrm{H}-5$ to $\mathrm{H}-9, \mathrm{H}_{3}-22$ to $\mathrm{H}_{3}-24$ and $\mathrm{H}_{3}-25$ as well as the values of coupling constants between $\mathrm{H}-14$ and $\mathrm{H}-18$ [52].

A polyhydroxy sesterterpenoid, $3 \alpha, 8 \alpha, 13,14$-erythro-tetrahydroxy-labd-15,17-dien16,19-olide (10) (Figure 5), was isolated from the acetone extract of the aerial parts of S. palaestina Bentham, collected in Jordan. The structure of $\mathbf{1 0}$ was established based on 
extensive analysis of $1 \mathrm{D}$ and 2D NMR spectra and HRMS data. The stereochemistry of C-13/C-14 diol was determined as erythro by observation of the ${ }^{1} \mathrm{H}$ NMR signals of the acetonyl methyl groups of its acetonide derivative, which appeared as two separated three-proton singlets at $\delta_{\mathrm{H}} 1.29$ and 1.56 [53]. Another C-23 methyl sesterterpene, $6 \alpha, 8 \alpha, 15 S$-trihydroxy-labd-13(14),17-dien-16S,19-olide (11) (Figure 5), was isolated from the $\mathrm{CHCl}_{3}-\mathrm{MeOH}$ extract of the aerial parts of S. dominica L., collected at As-Subayhhi, in Al-Balqa Province, Jordan, by a Sephadex LH-20 column chromatography, solid-phase extraction (SPE) and purified by reversed-phase HPLC. The structure of $\mathbf{1 1}$ was established by 1D and 2D NMR spectral analysis and HRMS data [54].

Investigation of the Arabidopsis genome revealed that the putative sesterterpene gene clusters consist of geranylfarnesyl diphosphate synthase (GFPPS), terpene synthase (TPS), and cytochrome P450s. Therefore, the functional identification of GFPPS-sesterTPS-P450 gene clusters of Arabidopsis in vitro, and subsequent detection of sesquiterpenes in planta were achieved. Furthermore, subcellular localization of identified enzymes involved in sesterterpene biosynthesis suggested that sesterterpenes (GFPPSs and sesterTPSs) are produced from the plastidial 2-C-methyl-D-erythritol 4-phosphate (MEP) pathway. Due to the presence of GFPPS-TPS-P450 clusters in the Arabidopsis genome, the TPSs located in these biosynthetic gene clusters were investigated to verify if they utilize GFPP as a substrate to produce sesterterpene backbones (even though no sesterterpene has been reported previously in Arabidopsis). By using different expression systems, 18 Brassicaceaespecific sesterTPSs were characterized, and 20 sesterterpene products were purified and elucidated. Moreover, phylogenetic analysis of plant TPS sequences clearly showed that functional sesterTPSs evolved from the TPS-a subfamily, the members of which always utilize GPP and/or FPP as substrates. However, since plant sesterTPSs have been identified only from Brassicaceae, it is still unclear whether the sesterTPSs from other plant species, such as Lamiaceae, evolved from the TPS-a subfamily or from other TPS subfamilies [50].

Based on this finding, $\mathbf{9}$ is hypothesized to be generated by allylic hydroxylation at $\mathrm{C}-16$ of the side chain of the bicyclic sesterterpene skeleton formed by cyclization of GFPP. Oxidation of the hydroxyl group at C-19 gives the intermediate $\mathbf{I}$, which undergoes lactonization between $\mathrm{OH}-16$ and the carboxylic acid at $\mathrm{C}-19$ to give II. The intermediate II can proceed in two directions. First, hydroxylation at C- 6 and C-15 leads to the formation of 11. On the other hand, hydroxylation at $\mathrm{C}-15$ and epoxidation of the double bond between C-13 and C-14 produces III. Hydrolysis of the 13,14-epoxide and dehydration of $\mathrm{OH}-15$ in III gives rise to 10 (Figure 5).

\subsubsection{Bicyclic Sesterterpene Lactones Containing C-23 Hydroxymethyl Group}

By using CC of silica gel, followed by Sephadex LH-20 and semi-preparative HPLC, (13E)-8 $\alpha, 23$-dihydroxy-labd-13(14),17(18)-dien-16,19-olide (12) (Figure 6) was isolated from a defatted fraction of $\mathrm{CH}_{2} \mathrm{Cl}_{2}$-soluble extract of $S$. tingitana, collected in San Remo, Italy. The structure of $\mathbf{1 2}$ was established by HRESIMS data, and 1D and 2D NMR spectral analysis. The relative configuration of $\mathbf{1 2}$, determined by NOESY correlations, was identical to that of 9 [52].

Salvisyriacolide (13) (Figure 6), a polar sesterterpene lactone with four hydroxyl groups, was isolated from the $\mathrm{MeOH}$-soluble fraction of $S$. syriaca L., collected in the North of Taleghan, Iran. The structure of $\mathbf{1 3}$ was established by extensive NMR spectral analysis. In order to determine the relative configuration, $\mathbf{1 3}$ was acetylated to give its triacetate (13a), which exhibited nuclear Overhauser effects (NOE) between H-24 and H-6 (8\%), H-25 and H-6 (10\%), H-9 and H-5 (8\%), H-22 and H-6 (8\%), as well as H-22 and H-25 (8\%) [55]. 
<smiles>CC1=CC(=O)OC1C/C=C(\O)CC1OC(=O)C=C1C</smiles>

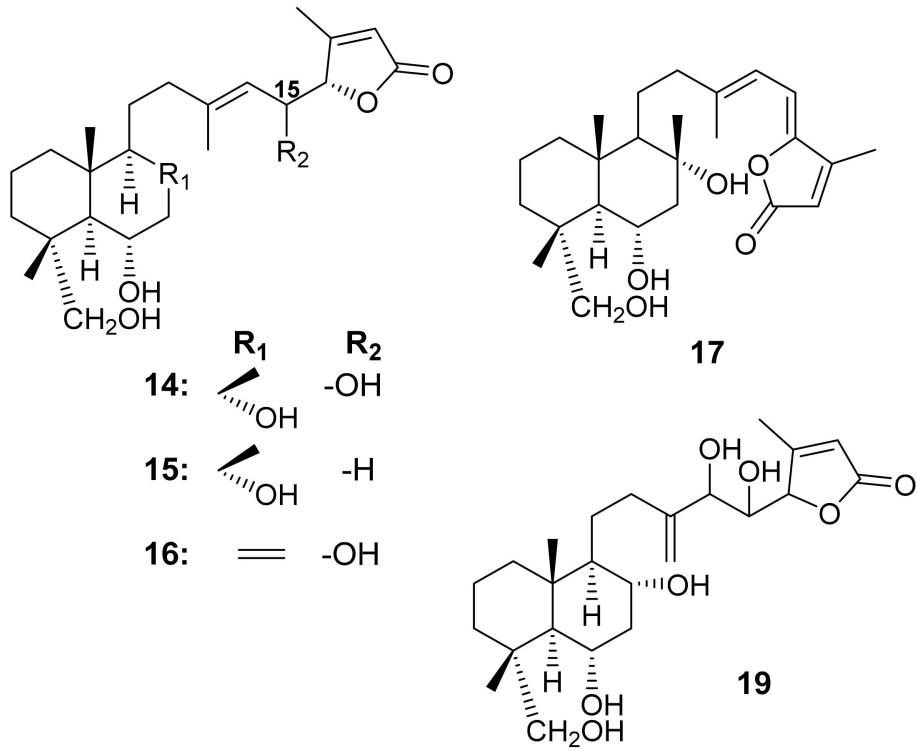

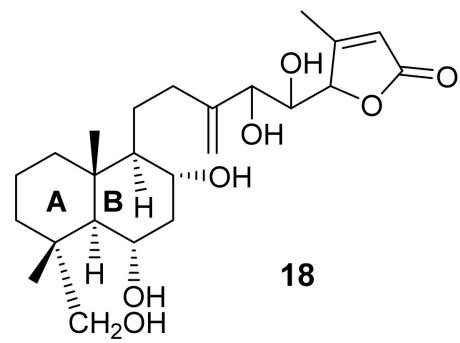<smiles>CC1=CC(=O)OC1C(O)C(O)C(C)(O)CC[C@]1(C)[C@@H](O)C[C@@H](O)[C@]2(C)[C@@H](C)CCC[C@]12C</smiles>

Figure 6. Structures of 12-20.

Dal Piaz et al., in their screening program for tubulin-tyrosine ligase (TTL) inhibitors, have identified a series of C-23 hydroxymethyl sesterterpenoids from the aerial parts of S. dominica L., obtained at As-Subayhhi in Al-Balqa Province, Jordan. By using a Sephadex LH-20 column chromatography, SPE, and reversed-phase HPLC, the $\mathrm{CHCl}_{3}$ $\mathrm{MeOH}$ fraction furnished the following sesterterpene lactones: $6 \alpha, 8 \alpha, 15 S, 23$-tetrahydroxylabd-13(14),17-dien-16S,19-olide (14), 6 $\alpha, 8 \alpha, 23$-trihydroxy-labd-13(14),17-dien-16R,19-olide

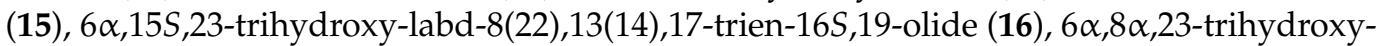

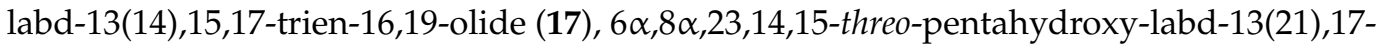

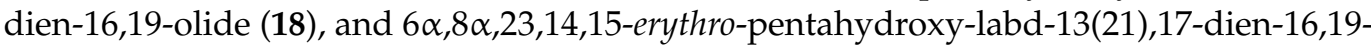
olide (19) (Figure 6). The structures of 14-19 were established by 1D and 2D NMR spectral analysis and ESI-MS. The relative configurations of C-4, C-5, C-6, C-8, C-9, and C-10 in 14 were determined based on coupling constant values for $\mathrm{H}-5, \mathrm{H}-6$, and $\mathrm{H}-9$, and their $\alpha$ orientation was established by ROESY correlations from $\mathrm{H}-9$ to $\mathrm{H}-5, \mathrm{Me}-22$ to $\mathrm{Me}-24$ and Me-25. Moreover, the absolute configuration of C-15 was determined as $R$ by a modified Mosher's method. The stereochemistry of rings A and B of 18 and 19 were identical to that of 14. In order to determine the relative configurations of C-14 and C-15 in 18 and 19, their acetonides were obtained. The ${ }^{1} \mathrm{H}$ NMR spectrum showed that both the acetonyl methyl groups in 18 appeared as one singlet at ca. $\delta_{\mathrm{H}}$ 1.31, while those of $\mathbf{1 9}$ appeared as two singlets at $\delta_{\mathrm{H}} 1.30$ and 1.56, indicating that the relative configurations of C-14 and C-15 in 18 and 19 are threo and erythro, respectively [54]. The same authors have further investigated the defatted acetone extract of $S$. dominica using liquid chromatography coupled with mass spectrometry (LC-MS). In addition to $6 \alpha, 8 \alpha, 13,23,14,15$-threo-hexahydroxy-labd-17en-16,19-olide (20) (Figure 6), 14-19 were identified in a single step. Compound 20 was identified by MS and MS/MS fragmentations. The main characteristic MS pattern of 20 displayed a sodium adducted ion peak $[\mathrm{M}+\mathrm{Na}]^{+}$at $m / z 493$, and its collision-induced frag- 
mentation generated fragment ion at $m / z 463$ (-30 amu), indicating that $\mathrm{CH}_{2} \mathrm{OH}$ is linked to $\mathrm{C}-4$. Moreover, a product ion at $m / z 249\left[\mathrm{C}_{11} \mathrm{H}_{14} \mathrm{O}_{5}+\mathrm{Na}\right]^{+}$was observed, suggesting a side chain carrying three hydroxyl groups [56].

\subsubsection{Bicyclic Sesterterpene Lactones Containing C-23 Formyl Group}

A series of C-23 formyl bicyclic sesterterpene lactones, including $6 \alpha, 8 \alpha, 15(S)$-trihydroxy23-oxo-labd-13(14),17-dien-16S,19-olide (21), 6 $\alpha, 8 \alpha$-dihydroxy-23-oxo-labd-13(14),17-dien16R,19-olide (22), 6 $\alpha, 15(S)$-dihydroxy-23-oxo-labd-8(22),13(14),17-trien-16S,19-olide (23), $6 \alpha, 8 \alpha$ dihydroxy-23-oxo-labd-13(14),15,17-trien-16,19-olide (24), 6 $\alpha, 8 \alpha, 14,15$-threo-tetrahydroxy-23-

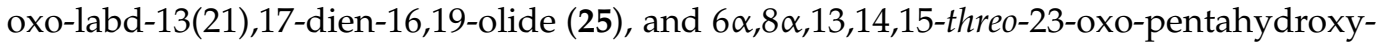
labd-17-en-16,19-olide (26) (Figure 7) was reported from the $\mathrm{CHCl}_{3}-\mathrm{MeOH}$ extract of the aerial parts of $S$. dominica L. The structures of 21-26 were established by 1D and 2D NMR spectral analysis and ESIMS data. In the case of 21, 1D-ROESY experiments established the $\alpha$-orientation of $\mathrm{CHO}-23$, i.e., irradiation of Me-24 at $\delta_{\mathrm{H}} 1.18$ increased the intensity of Me-25 and Me-22 signals. Comparison of the NMR spectral data of 24 with those of 14 and 17 revealed that 24 and $\mathbf{1 7}$ have the same side chain but differ in the bicyclic moiety, whereas the bicyclic moiety of $\mathbf{1 4}$ and $\mathbf{1 7}$ are identical. The structure of $\mathbf{2 6}$ was proposed based on the presence of $[\mathrm{M}+\mathrm{Na}]^{+}$at $m / z 491$, indicating its molecular mass of $468 \mathrm{amu}$, which is 2 amu less than the molecular mass of 20. Like 20, its MS/MS spectrum showed signals at $m / z 393$ and $m / z$ 249, indicating that $\mathbf{2 6}$ has the same side chain as 20. Moreover, the signal at $m / z 401$ was indicative of the presence of five eliminable hydroxyl groups. On the other hand, no ion produced by the elimination of the group linked to C-4 was detected [54,56].

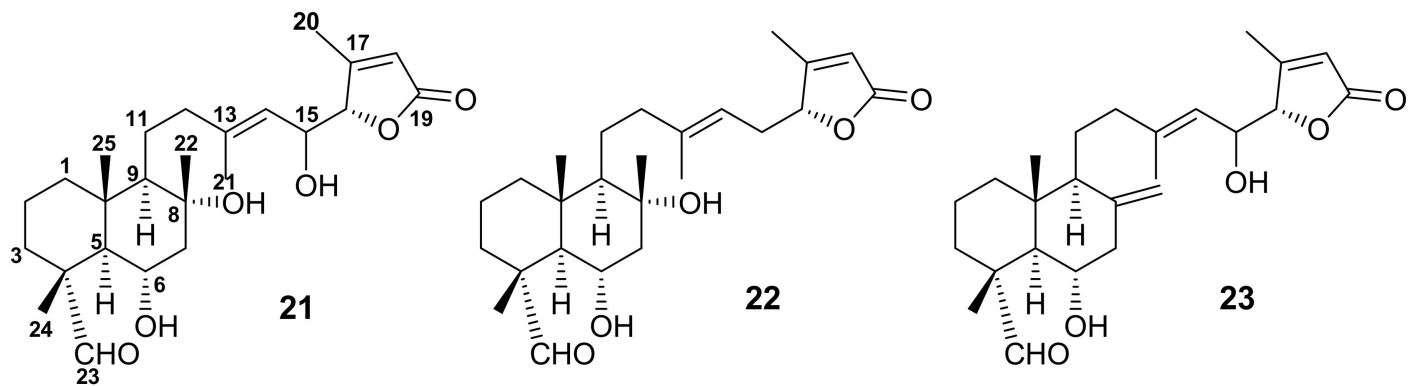<smiles>C/C(C=O)=C/CCC1[C@](C)(O)C[C@@H](O)[C@]2(C)CCCC(C)(C)[C@@]12C</smiles>

24<smiles>CC1=CC(=O)OC1C(O)C(O)C(=O)CC[C@@]1(C)[C@@H](O)C[C@@H](O)[C@]2(C)[C@@](C)(CO)CCC[C@@]21C</smiles><smiles>CC1=CC(=O)OC1C(O)C(O)C(C)(O)CC[C@]1(C)[C@H](O)C[C@@H](O)[C@]2(C)[C@](C)(CO)CCC[C@]12C</smiles>

Figure 7. Structures of 21-26.

\subsubsection{Bicyclic Sesterterpene Lactones Containing C-23 Carboxylic Acid}

Salvimirzacolide (27) (Figure 8), a bicyclic sesterterpene lactone whose C-23 possesses a carboxylic acid function, was isolated from the $\mathrm{MeOH}$-soluble portion of an acetone extract of the aerial parts of S. mirzayanii Rech. and Esfandieri, collected from Malek and Adori villages near Kerman, Iran. Extensive NMR spectral analysis, in combination with $X$-ray analysis, revealed that $\mathbf{2 7}$ is a normal bicyclic sesterterpene (with $10 R$ configuration) containing a $\gamma$-butyrolactone ring with the $R$-configuration at C-16 [57]. 


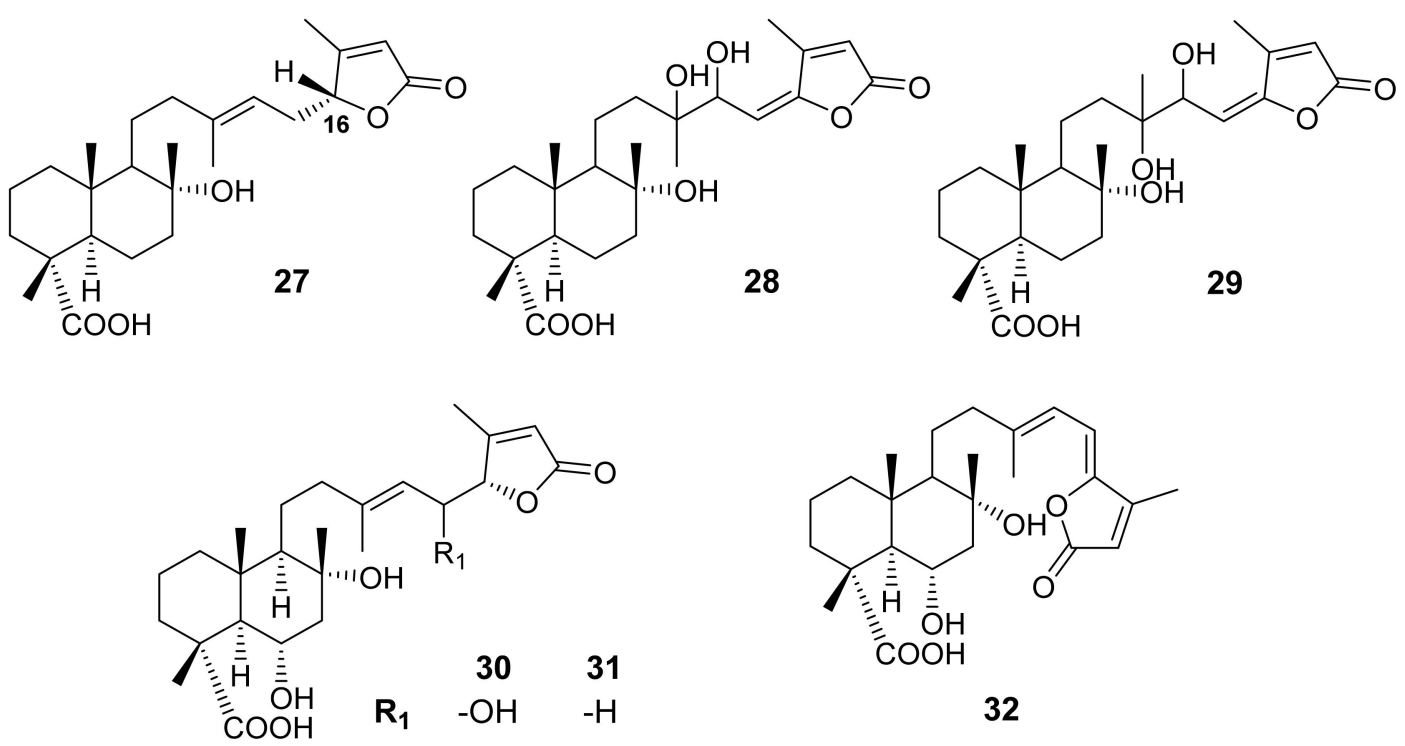

Figure 8. Structures of 27-32.

The sesterterpene lactones 8 $\alpha, 13,14$-threo-trihydroxy-labd-15,17-dien-16,19-olide-23oic acid (28) and 8 $\alpha, 13,14$-erythro-trihydroxy-labd-15,17-dien-16,19-olide-23-oic acid (29) (Figure 8) were also isolated from the acetone extract of the aerial parts of S. palaestina Bentham, collected in Jordan. The NMR data of 28 and 29 were very similar except for the signals of $\mathrm{H}-12, \mathrm{H}-14, \mathrm{C}-13, \mathrm{C}-14, \mathrm{C}-21$ and Me-21, suggesting that they are epimers at C-13/C-14. The relative configurations of C-13/C-14 vic-diol of 28 and 29 were established as threo and erythro, respectively, by observing the methyl signals of their acetonides in the ${ }^{1} \mathrm{H}$ NMR spectra [53].

The sesterterpene lactones $6 \alpha, 8 \alpha, 15(S)$-trihydroxy-23-carboxy-labd-13(14),17-dien-

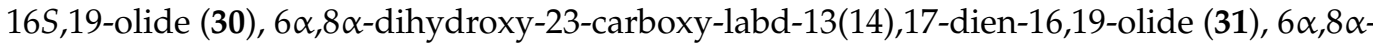
dihydroxy-23-carboxy-labd-13(14),15,17-trien-16,19-olide (32) (Figure 8) were isolated from the $\mathrm{CHCl}_{3}-\mathrm{MeOH}$ fraction of the aerial parts of S. dominica. The structures of 30-32 were established by analysis of ${ }^{1} \mathrm{H}$ and ${ }^{13} \mathrm{C}$ NMR spectra and ESIMS data [54].

\subsubsection{Bicyclic Sesterterpene Lactones Containing C-23 Methyl Ester of Carboxylic Acid}

In 1982, Rustaiyan et al. first described the isolation of a bicyclic sesterterpene lactone with a methyl ester of carboxylic acid at C-23 and named it salvileucolide methyl ester (33) (Figure 9) from a diethyl ether extract of the aerial parts of S. hypoleuca Benth, collected from the north of Teheran, Iran [58]. Later, Rustaiyan and Sadjadi also reported the isolation of 33 (Figure 6) from a MeOH-soluble fraction of S. syriaca L., collected from north of Taleghan, Iran [55]. Moghaddam et al. also reported the isolation of $\mathbf{3 3}$ from the aerial parts of $S$. sahendica Boiss \& Buhse, an endemic plant of Iran which was collected in Bostanabad, East of Tabriz. However, neither the relative nor absolute configuration of C-16 in 33 was determined [59]. Only in 1996 did Linden et al. [60] succeed in determining the absolute configuration of the stereogenic carbons in 33 by performing an X-ray analysis of 6-O- $p$ bromobenzoyl ester of 33 (33"; Figure 9), whose ORTEP diagram putatively indicated the $R$-configuration at C-10 and C-16 [60]. Furthermore, salvileucolide methyl ester (SME) derivatives, viz. 14-hydroperoxy-13(21)-dehydro-SME (34), 13-hydroperoxy-14-ene-SME (35), 13-epi-hydroperoxy-14-ene-SME (36), and 14,17-cycloperoxy-13(21)-dehydro-SME (37) (Figure 9), were also isolated from the polar fraction of the aerial parts of S. hypoleuca. The structures of 34-37 were established by NMR spectral analysis [61]. 


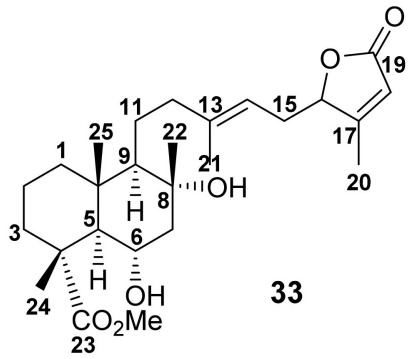



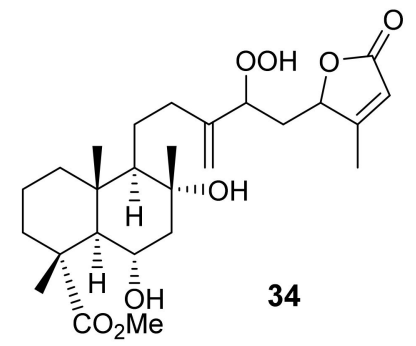

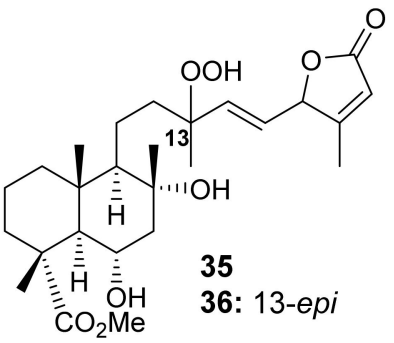

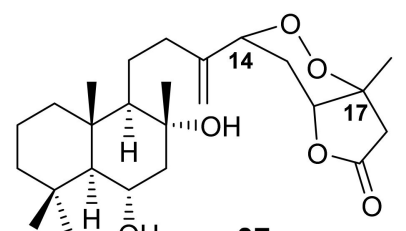

37

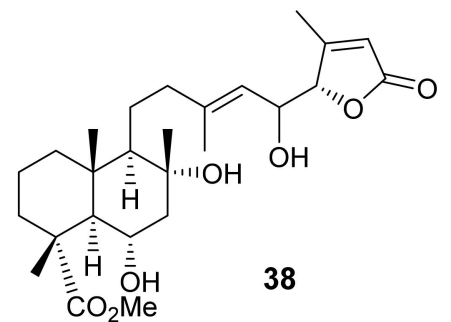

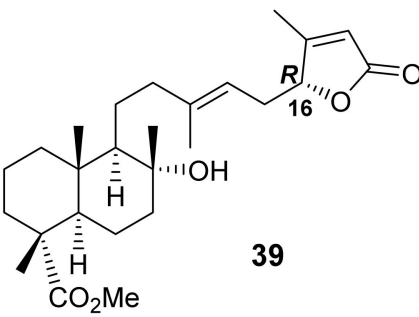

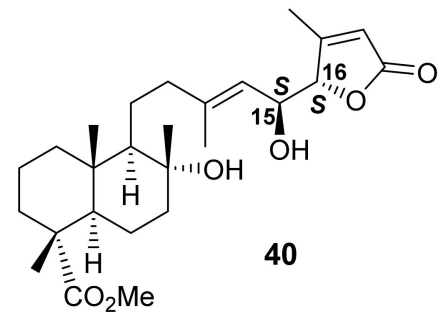

Figure 9. Structures of 33-40.

Further bicyclic sesterterpene lactones containing C-23 carboxylic acid methyl ester such as $6 \alpha, 8 \alpha, 15(S)$-trihydroxy-23-carboxymethyl-labd-13(14),17-dien-16S,19-olide (38) were isolated from $S$. dominica L. [54], while $(4 R, 5 R, 8 R, 9 R, 10 S, 16 R, 13 E)-8$-hydroxy-23carboxymethyl-labd-13(14),17(18)-dien-16,19-olide (39) and (4R,5R,6S,8R,9R,10S,15S,16S,13E)8,15-dihydroxy-23-carboxymethyl-labd-13(14),17(18)-dien-16,19-olide (40) (Figure 9) were isolated from $S$. tingitana Etl. That the relative configuration of $\mathbf{3 9}$ and $\mathbf{4 0}$ was the same as that of 33 was based on the values of coupling constants of $\mathrm{H}-5(J=12.0$ and $2.3 \mathrm{~Hz})$ as well as NOESY correlations between $\mathrm{H}-5$ and $\mathrm{H}-9$, and between $\mathrm{H}_{3}-22, \mathrm{H}_{3}-24$, and $\mathrm{H}_{3}-25$ of 39 and 40, which were consistent with a $\beta$-orientation of Me-22, Me-24, and Me-25 as well as a trans junction of the decalin ring system. Additionally, the absolute configuration of $\mathrm{C}-15$ was determined as $S$ by the Mosher's method. Moreover, the vibrational circular dichroism (VCD) spectra of $\mathbf{3 9}$ and $\mathbf{4 0}$ were recorded and compared to their calculated spectra at the B3LYP / 6-31+G(d,p) level of theory. It was found that the experimental and calculated VCD spectra showed a significantly better fit for the $(4 R, 5 R, 8 R, 9 R, 10 S, 16 R)-39$. On the other hand, the VCD similarity analysis gave no clear preference to any of the four calculated spectra for 40 [52].

\subsubsection{Bicyclic Sesterterpenes Containing C-6, 23- and C-16, 19-Diolide}

Salvileucolide-6,23-lactone (41) (Figure 10), the first 6,23-lactone-containing sesterterpene reported from Salvia plants, was isolated from the diethyl ether extract of the aerial parts of S. hypoleuca Benth. Like 33, the structure of $\mathbf{4 1}$ and the stereochemistry at C-5 and C-6 were established based on the observation of the ${ }^{1} \mathrm{H}$ NMR spectrum through spin decoupling and the addition of the chemical shift reagent, $\mathrm{Eu}(\mathrm{fod})_{3}$, and the ${ }^{13} \mathrm{C} \mathrm{NMR}$ spectrum. However, the relative and absolute configurations of C-16 were not determined [58]. 

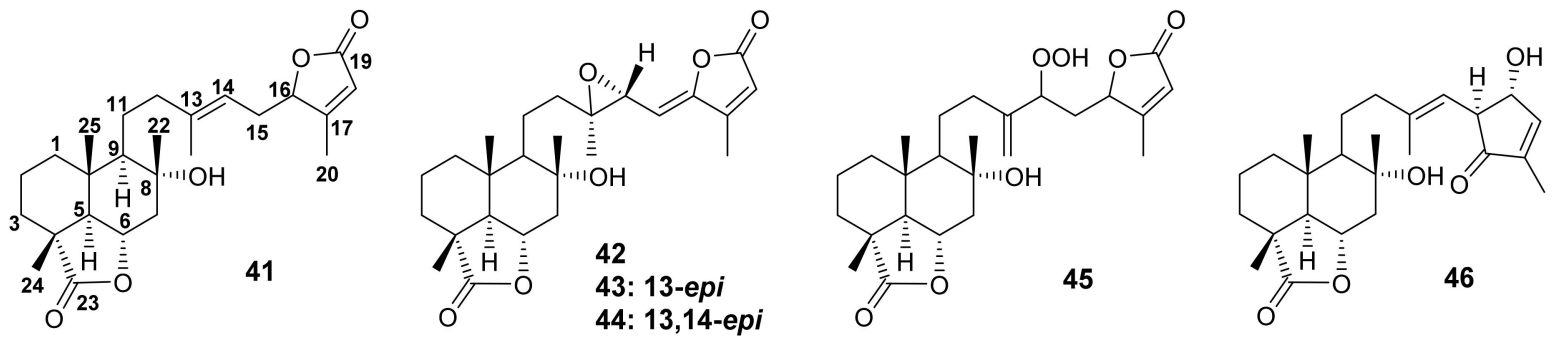

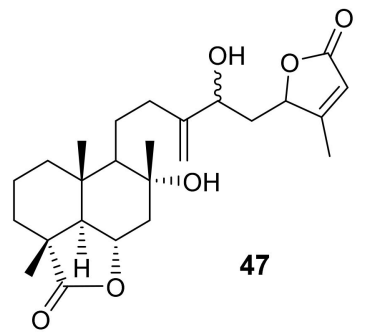

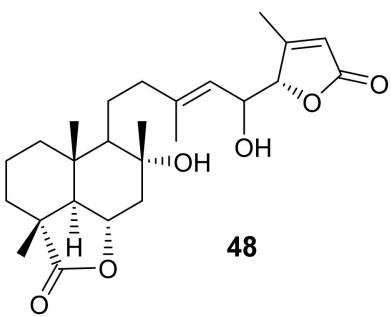

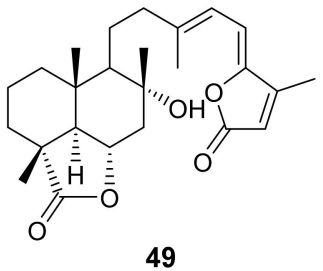

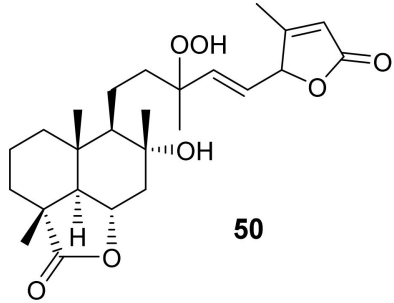

Figure 10. Structures of 41-50.

The polar fraction of the aerial parts of S. hypoleuca also furnished 15,16-dehydrosalvileucolide6,23-lactone-trans-epoxide (42), 15,16-dehydrosalvileucolide-6,23-lactone-cis-epoxide (43), and 15,16-dehydrosalvileucolide-6,23-lactone-13,14-bis-epi-trans-epoxide (44), 14-hydroperoxy13(21)-dehydro-13,14-dihydro-salvileucolide-6,23-lactone (45), and salvileucolide (46), a sesterterpene with a 4-hydroxycyclopent-2-en-1-one moiety (Figure 10). The structures of 42-46 were identified by detailed analysis of ${ }^{1} \mathrm{H}$ NMR spectra using a double irradiation technique. The structure of the 4-hydroxycyclopent-2-en-1-one in 46 was postulated to derive from a hydrolysis of 19,16-lactone in $\mathbf{4 1}$ to give a $\gamma$-hydroxy carboxylic acid in IV. Oxidation at $\mathrm{OH}-16$ to ketone and reduction of $\mathrm{COOH}-19$ to aldehyde yield the intermediate $\mathbf{V}$. Aldol condensation of the intermediate $\mathbf{V}$ led to a formation of the 4-hydroxycyclopent2-en-1-one moiety in 46 (Figure 11) [61].

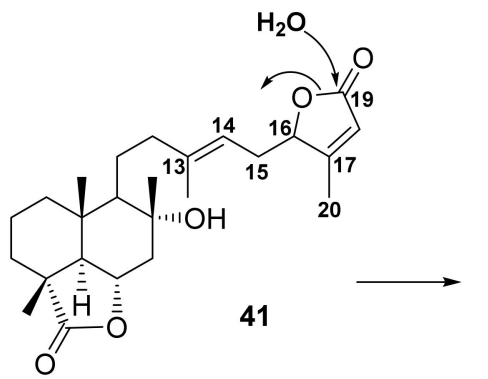

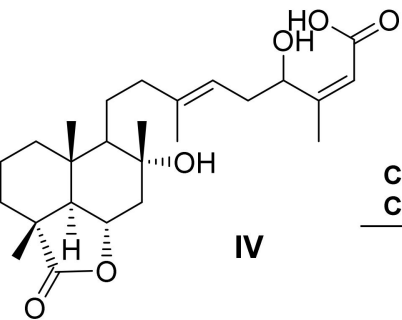

C-16 Oxidation C-19 Reduction

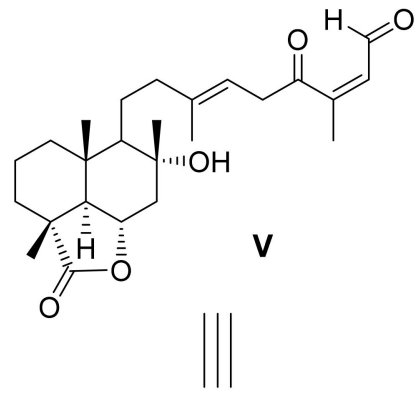

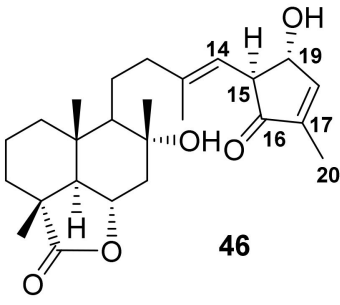

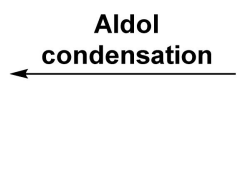<smiles>C/C(=C/C(=O)C/C(C)=C/CC[18F])C(=O)O</smiles>

Figure 11. Proposed mechanism for the formation of 4-hydroxycyclopent-2-en-1-one in $\mathbf{4 6 .}$

Lachnocalyxolide B (47) (Figure 10) was isolated from a defatted acetone extract of the aerial parts of S. lachnocalyx Hedge, collected from Eghlid in the Fars Province, Iran. The structure of 47 was established by 1D and 2D NMR spectral analysis and HR-ESIMS data. The relative configuration of 47 was established based on NOESY correlations from 
$\mathrm{H}-6 \beta$ to $\mathrm{H}_{3}-22, \mathrm{H}_{3}-24, \mathrm{H}_{3}-25$, and $\mathrm{H}-7 \beta$, as well as from $\mathrm{H}-5 \alpha$ to $\mathrm{H}-9 \alpha$. However, the relative configurations at $\mathrm{C}-14$ and $\mathrm{C}-16$ were not assigned because of high conformational flexibility and free rotation around C-14/C-15 and C-15/C-16 [62].

The $\mathrm{CHCl}_{3}-\mathrm{MeOH}$ extract of the aerial parts of $S$. dominica $\mathrm{L}$. also furnished $8 \alpha, 15(S)$ dihydroxy-labd-13(14),17-dien-23,6 $\alpha$-16S,19-diolide (48) and 8 $\alpha$-hydroxy-labd-13(14),15,17trien-6 $\alpha, 23-16,19$-diolide (49) (Figure 10). The structures of 48 and 49 were established by analysis of ESIMS and ${ }^{1} \mathrm{H}$ and ${ }^{13} \mathrm{C}$ NMR spectra. In the case the of 48, the ROESY spectrum displayed correlations between Me-22, Me-24, and Me-25, thus confirming the $\alpha$-orientation of hydroxyl group on C-8 [54].

A further sesterterpene diolide, $8 \alpha$-hydroxy-13-hydroperoxylabd-14,17-dien-19,16;23,26 $\alpha$ diolide (50) (Figure 10), was isolated from the acetone extract of the aerial parts of $S$. $s a-$ hendica, collected between Tabriz and Bostanabad, East Azerbaijan Province, Iran. The structure of 50 was elucidated by detailed analysis of 1D and 2D NMR experiments and HRESIMS. The relative configuration of the lactonized C- 6 was determined as $\alpha$, based on the coupling constant of H-6 with H-5 $\left(J_{5,6}=11 \mathrm{~Hz}\right)$ as well as by NOESY correlations from $\mathrm{H}-6$ to $\mathrm{H}_{3}-22, \mathrm{H}_{3}-24$ and $\mathrm{H}_{3}-25$, all of which are $\beta$-oriented. Moreover, $\mathrm{H}-5$ and $\mathrm{H}-9$ also showed a NOESY correlation, implying a $\beta$-orientation of the side chain on C-9. However, the configurations of C-13 and C-16 were not determined [63].

\subsubsection{Bicyclic Sesterterpenes Containing C-19,16-Olide and C-6,23-Tetrahydrofuran}

The $\mathrm{CHCl}_{3}-\mathrm{MeOH}$ extract of the aerial parts of $S$. dominica L. also furnished 23,6 $\alpha-$ epoxy-labd-8,13(14),17-trien-16R,19-olide (51), 15(S)-dihydroxy-23,6 $\alpha$-epoxy-labd-13(14),17-

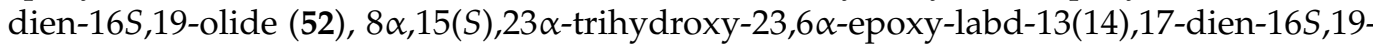
olide (53), $8 \alpha, 15(S)$-dihydroxy-23 $\alpha$-O-ethyl-23,6 $\alpha$-epoxy-labd-13(14),17-dien-16S,19-olide (54), $8 \alpha$-hydroxy-23 $\alpha$-O-ethyl-23,6 $\alpha$-epoxy-labd-13(14),17-dien-16R,19-olide (55), and 8 $\alpha, 23-$ dihydroxy-23,6 $\alpha$-epoxy-labd-13(14),15,17-trien-16,19-diolide (56) (Figure 12). The structure of 51-56 were elucidated by analysis of 1D and 2D NMR spectra and HR-ESIMS data. The relative configuration of $\mathbf{5 1}$ was established by ROESY correlations, while the absolute configuration at C-15 of 52 was determined by a modified Mosher's method. The decalin ring junction and the stereochemistry of the side chains of 51-56 were identical to those of 14 [54].

The $n$-hexane-insoluble portion of the $\mathrm{CH}_{2} \mathrm{Cl}_{2}$ extract of the fresh aerial parts of $S$. tingitana also furnished $(4 R, 5 R, 6 S, 8 R, 9 R, 10 S, 16 R, 23 S, 13 E)-8,23$-dihydroxy-23,6-epoxylabd-13(14),17(18)-dien-16,19-olide (57), (13E)-8 $\alpha$-hydroxy-23 $\alpha$-O-methyl-23,6 $\alpha$-epoxy-labd13(14),17(18)-dien-16,19-olide (58), (4R,5R,6S,8R,9R,10S,15S,16S,23S,13E)-8,15-dihydroxy-23O-methyl-23,6-epoxy-labd-13(14),17(18)-dien-16,19-olide (59) (Figure 12). The relative configurations at C-4, C-5, C-6, C-9, and C-10 of 57, 58 and 59 were established based on the coupling constants of $\mathrm{H}-5, \mathrm{H}-6$, and $\mathrm{H}-9$ as well as by NOESY correlations from H-6 to $\mathrm{H}_{3}-22, \mathrm{H}_{3}-24$, and $\mathrm{H}_{3}-25$, and from $\mathrm{H}-5$ to $\mathrm{H}-9$. By using a modified Mosher's method, the configuration of C-15 in $\mathbf{5 9}$ was assigned as $15 S$. Tentative assignment of the absolute configurations of C-15 and C-16 by comparison of the calculated and experimental VCD spectra was unsuccessful since the results were in conflict with that obtained from the Mosher's method. Therefore, the absolute configuration of C-16 in 57 and 59 was assigned by comparison of the NMR data with those reported for the congeners [52].

Hasan et al. isolated salvidominicolide B (60) (Figure 12) from the aqueous $\mathrm{MeOH}$ portion of the $\mathrm{CHCl}_{3}$ extract of whole parts of $S$. dominica L., which was collected in AlMastaba region, Jordan. The structure of 60 was established by detailed analysis of 1D and 2D NMR spectra and HRMS data [64]. 


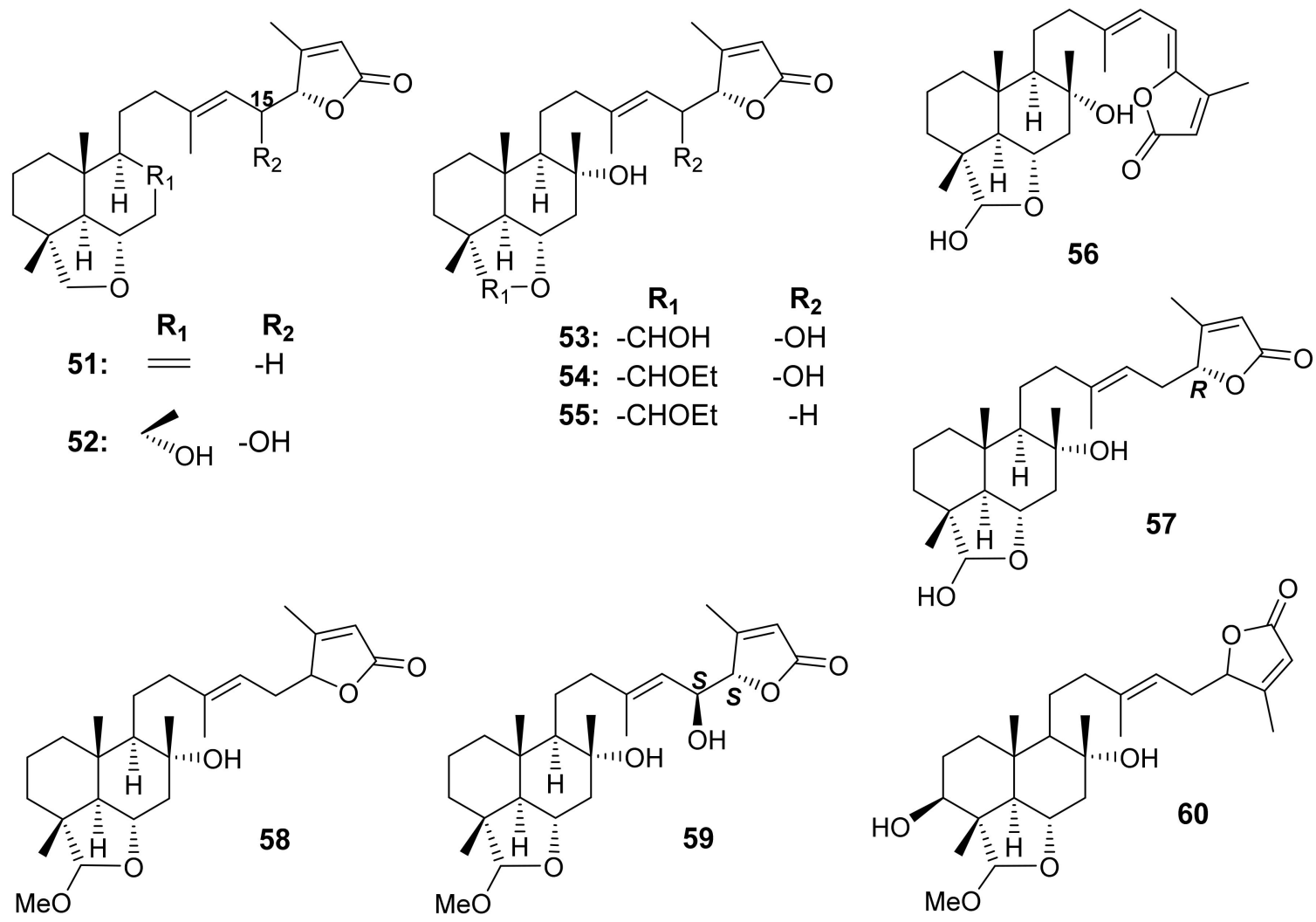

Figure 12. Structures of 51-60.

\subsection{Tricyclic Sesterterpenoids}

So far, 21 tricyclic sesterterpenoids containing a tetrahydropyran ring, angularly fused with a decalin ring system, have been reported from six Salvia species viz. S. aethiopis, S. dominica, S. yosgadensis, S. tingitana, S. lachnocalyx, and S. mirzayanii. Like bicyclic sesterterpenoids, this group of sesterterpenoids is categorized as C-23 methyl, C-23 carboxylic acid, C-23 carboxylic acid methyl ester, C-23,6 and C-16,19 diolides. The biosynthetic pathway of these compounds could originate from 8, 16-dihydroxy bicyclic sesterterpene containing $\gamma$-lactone, 11, followed by nucleophilic addition of $\mathrm{OH}-8$ to $\mathrm{C}-13$ of the double bond with concomitant elimination $\mathrm{OH}-15$ of the side chain to give VI. Epoxidation of VI gives VII, which upon hydroxylation of the C-14/C-15-epoxide gives VIII. Elimination of $\mathrm{OH}-15$ by dehydration leads to a formation of 63. Nucleophilic addition of the double bond at $\mathrm{C}-16$ by $\mathrm{H}_{2} \mathrm{O}$ would give IX, which after dehydration generates a double bond between C-14 and 15 and a hemiacetal function at C-16 in 64 (Figure 13).

Two $\gamma$-methoxybutenolide-containing sesterterpenes, 13-epi-salviaethiopisolide (61 and $61^{\prime}$ ) together with salviaethiopisolide (62 and $\mathbf{6 2} \mathbf{2}^{\prime}$ ) (Figure 14), were isolated from the $\mathrm{MeOH}$ extract of the aerial parts of $S$. aethiopis, collected in Spain. The ${ }^{1} \mathrm{H}$ and ${ }^{13} \mathrm{C}$ NMR spectra of both compounds displayed a duplicity of several signals, with a relative intensity of 55/45, suggesting that the compounds were a mixture of two epimers. The structures of both compounds were elucidated by 1D and 2D NMR spectral analysis as well as chemical transformation. Analysis of the NMR data of the acetylation and reduction products confirmed that both compounds were epimeric at C-16. The relative stereochemistry of 61/61' and 62/62' was determined by decoupling constants of each proton and the results of the NOE experiments that showed clear effects for $\mathrm{H}-25$ with $\mathrm{H}-24, \mathrm{H}-2$ and $\mathrm{H}-1, \mathrm{H}-24$ with $\mathrm{H}-23, \mathrm{H}-3$ with $\mathrm{H}-2, \mathrm{H}-24$ and $\mathrm{H}-23$, and $\mathrm{H}-5$ with $\mathrm{H}-9$ and $\mathrm{H}-1$, suggesting the $\beta$-orientation for Me-22, Me-24 and Me-25, and the $\alpha$-orientation for H-5 and H-9 [65]. 


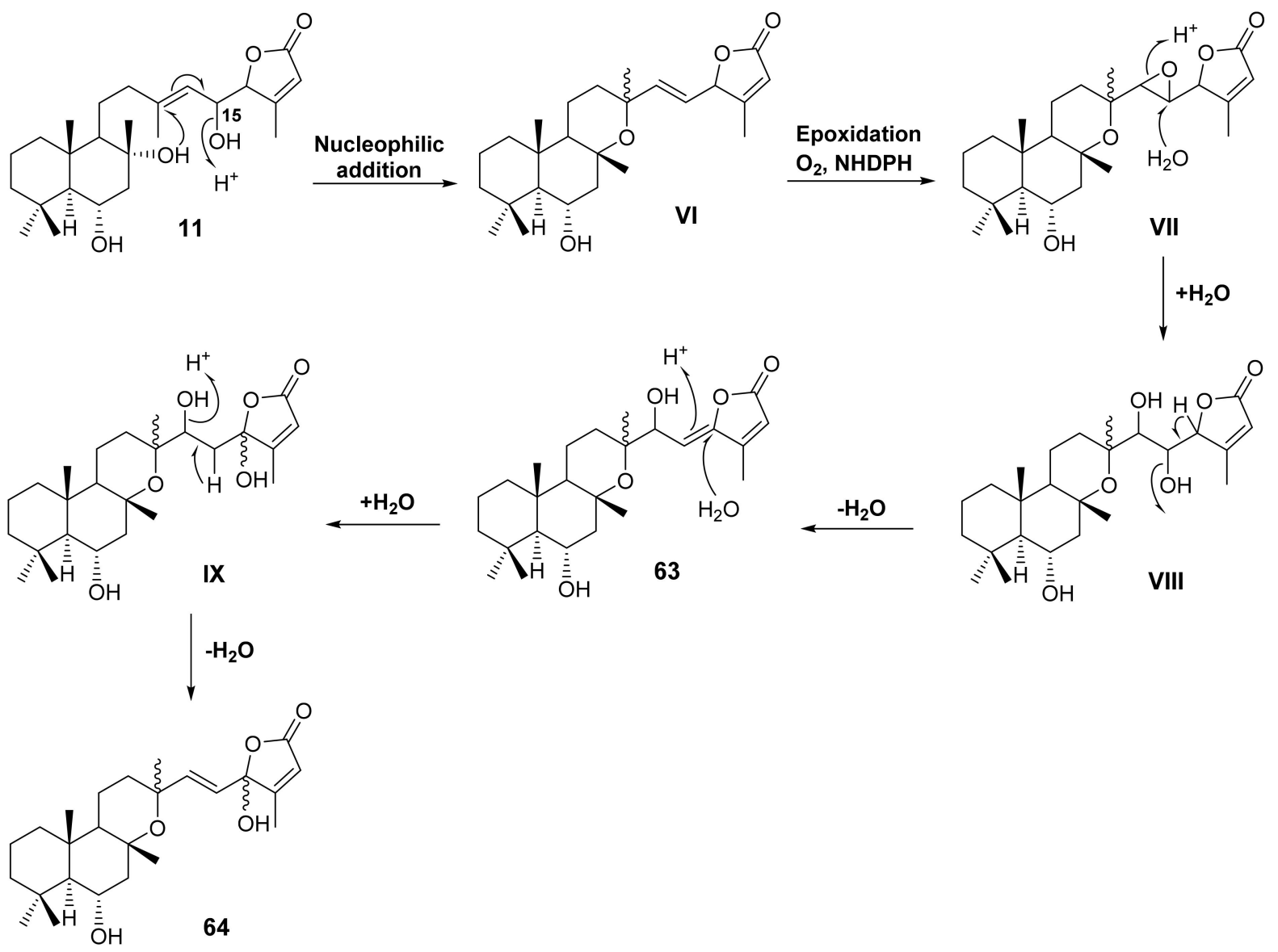

Figure 13. Proposed biosynthetic pathway for the formation of tricyclic sesterterpene lactones.

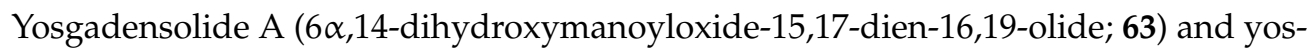
gadensolide B (6 $\alpha, 16$-dihydroxymanoyloxide-14,17-dien-16,19-olide; 64) (Figure 14) were isolated from the acetone extract of the aerial parts of $S$. yosgadensis Freyn et Bornm., collected in Turkey. In the case of 63 , the ${ }^{1} \mathrm{H}$ and ${ }^{13} \mathrm{C}$ NMR spectra of its two acetylation products were very similar except for the signals of C-14, C-15, C-18, and C-20, which were slightly different, indicating the possible presence of $E$ - and Z-stereoisomers (a \& $\mathbf{b})$. Thus, the structures of $\mathbf{6 3 a}$ and $\mathbf{6 3 b}$ were established as $6 \alpha, 14$-dihydroxymanoyloxide-15,17-dien15(Z)-16,19-olide and 6 $\alpha$,14-dihydroxymanoyloxide-15,17-dien-15(E)-16,19-olide, respectively (Figure 14). The ${ }^{1} \mathrm{H}$ and ${ }^{13} \mathrm{C}$ NMR spectra of another co-isolated compound (63c) resembled those of 63 except for the signals of H-14, H-15, Me-21 and Me-22, indicating its gross structure was similar to that of $\mathbf{6 3 a} / \mathbf{6 3 b}$. The authors suggested that $\mathbf{6 3}$ c was a C-13 epimer of 63; however, due to the limited amount of the compound, its stereochemistry was not investigated. In turn, the ${ }^{1} \mathrm{H}$ and ${ }^{13} \mathrm{C}$ NMR spectra of another co-isolated sesterterpene (64) were similar to those of $\mathbf{6 1}$ and $\mathbf{6 1} \mathbf{1}^{\prime}$, indicating the presence of a sesterterpene structure derived from manoyloxide, but with different side-chain from that of $\mathbf{6 1}$. However, careful analysis of the ${ }^{1} \mathrm{H}$ and ${ }^{13} \mathrm{C}$ NMR data of 64 revealed its similarity both in the side chain and in the main skeleton to those of $\mathbf{6 2 / 6 2 ^ { \prime }}$. The obvious difference is the presence of a hydroxyl group on C-16 in 64 instead of a methoxy group in $62 / 62^{\prime}$ and a secondary hydroxyl group on C-6 in 64 instead of on C-3 in 62/62'. Therefore, 64 was identified as $6 \alpha, 16$-dihydroxymanoyloxide-14,17-dien-16,19-olide (Figure 14). The ${ }^{1} \mathrm{H}$ and ${ }^{13} \mathrm{C}$ NMR data of another co-isolated sesterterpene lactone (64a) resembled those of 64 except for the chemical shift values of $\mathrm{H}-14, \mathrm{H}-15, \mathrm{Me}-21, \mathrm{Me}-22$, and Me-25, suggesting that 64a could be a C-13 epimer of 64 and this hypothesis was corroborated by NOE experiment. Therefore, the structure of 64a was elucidated as 6 $\alpha, 16$-dihydroxy-13-epi-manoyloxide-14,17-dien-16,19-olide (Figure 14) [66]. 
Three tricyclic sesterterpenes, viz. 3ß-hydroxymanoyloxide-14(E),17-dien-16-oxo-19-oic acid (65), hydroxymanoyloxide-14,17-dien-16-oxo-19-oic acid (66), and hydroxymanoyloxide14,17-dien-16-oxo-19,23-dioic acid (67) (Figure 14) were isolated from the $\mathrm{CHCl}_{3}$ extract of the aerial part of $S$. aethiopis L., obtained from plants cultivated in a greenhouse at Instituto di Genetica Vegetale, CNR, Portici, Napoli, Italy. The structures of 65-67 were established by $1 \mathrm{D}$ and $2 \mathrm{D}$ NMR spectral analysis and HR-ESIMS data. The relative stereochemistry at C-5, C-8, C-9, C-10, and C-13 was established by the values of coupling constant of H-5 and $\mathrm{H}-9$ while their axial orientation was determined by observation of cross peaks from $\mathrm{H}-9$ to $\mathrm{H}-5, \mathrm{Me}-25, \mathrm{Me}-21$ to Me-22 in the NOESY spectrum, thus indicating a trans-anti-trans tricyclic moiety [67].

The manoyloxide-type sesterterpenes, 68-72 (Figure 14) were isolated from the acetone extract of the aerial parts of $S$. mirzayanii, an endemic species to Iran, which was collected at Geno Mountain in the Bandar Abbas, South of Iran. The structures of the compounds were elucidated by 1D and 2D NMR spectral analysis and HRESIMS data. The relative configurations of the compounds were established by NOESY correlations, while the absolute configurations at C-13 and C-14 of 68,69 and 70 were established by comparison of their calculated and experimental electronic circular dichroism (ECD) spectra. Therefore, the structures of 68, 69 and 70 were elucidated as $(4 R, 5 R, 8 R, 9 R, 10 S, 13 S, 14 S)$-14-hydroxymanoyloxide-15,17dien-15(Z)-16,19-olide, (4R,5R,8R,9R,10S,13R,14S)-14-hydroxymanoyloxide-15,17-dien-15(Z)16,19-olide, and (4R,5R,8R,9R,10S,13S,14R)-14-hydroxymanoyloxide-15,17-dien-15(Z)-16,19olide, respectively. On the other hand, due to high conformational flexibility and free rotation around C-14/C-15 in 71, the absolute configuration of C-14 could not be determined. Consequently, the structure of 71 was established as $(4 R, 5 R, 8 R, 9 R, 10 S, 13 S, 14 R)-14$ hydroxymanoyloxide-15,17-dien-15(Z)-16,19-olide. For 72, the ECD spectrum showed a positive Cotton effect (CE) at $290 \mathrm{~nm}\left(\mathrm{n} \rightarrow \pi^{*}\right.$ transition) and a negative CE at $235 \mathrm{~nm}$ ( $\pi \rightarrow \pi^{*}$ transition of $\alpha, \beta$-unsaturated- $\gamma$-butenolide). The calculated ECD spectrum of the $(4 R, 5 R, 8 R, 9 R, 10 S, 13 R)$-stereoisomer showed a strong positive CE at $290 \mathrm{~nm}$ that fitted well with the experimental data. However, the negative CE at $230 \mathrm{~nm}$ in the experimental spectrum was absent in the calculated spectrum. Therefore, the ECD spectrum for the $(4 R$, $5 R, 8 R, 9 R, 10 S, 13 S)$-stereoisomer was calculated but showed a negative CE at $290 \mathrm{~nm}$. Therefore, the optical rotations for both stereoisomers were also calculated and compared with the experimental data to confirm the absolute configuration, thus establishing the structure of 72 as $(4 R, 5 R, 8 R, 9 R, 10 S, 13 R)$-manoyloxide-15,17-dien-15(Z)-16,19-olide [68].

A manoyloxide-type sesterterpene with a furan-containing side chain and a carboxylic acid ester function at C-23, (14E)-methylmanoyloside-14,16,18-trien-16,19-oxide23-carboxilate (73) (Figure 14), was also isolated from the n-hexane-insoluble fraction of the $\mathrm{CH}_{2} \mathrm{Cl}_{2}$ extract of the aerial parts of $S$. tingitana. The structure of 73 was elucidated by extensive analysis of 1D and 2D NMR spectra and HR-ESIMS data. The NOESY correlations from $\mathrm{H}_{3}-22$ to $\mathrm{H}_{3}-24, \mathrm{H}_{3}-25$ and from $\mathrm{H}-5$ to $\mathrm{H}-9$ indicated that the relative configuration of 73 was the same as that of the previously reported manoyloxide-type sesterterpenoids. However, the relative configuration of C-13 remained unassigned due to overlapping signals of $\mathrm{H}_{3}-21$ and $\mathrm{H}_{3}-22$ [52].

Lachnocalyxolides A (74) and C (75) (Figure 14) were isolated from the ethyl acetate (EtOAc)-soluble fraction of the acetone extract of the aerial parts of S. lachnocalyx Hedge, collected in Iran. Like some previously discussed manoyloxide-type sesterterpenes, the ${ }^{1} \mathrm{H}$ NMR spectrum of 74 showed two pairs of signals of $\mathrm{H}-14$ and $\mathrm{H}-15$ while the ${ }^{13} \mathrm{C}$ NMR spectrum exhibited two pairs of the carbon signals of the two double bonds (C-15/C-16 and C-17/C-18) and one pair of a carbinol proton (C-14), indicating the presence of an epimeric pair (74 and $74^{\prime}$; Figure 14). Compound 75 was elucidated as a manoyloxide-type sesterterpene 6,23-olide with a hydroxyl group on $\mathrm{C}-14$ and an $\alpha, \beta$-unsaturated- $\gamma$-lactone in the side chain by ${ }^{1} \mathrm{H}$ and ${ }^{13} \mathrm{C}$ NMR data. The relative configuration of 75 was corroborated by NOESY correlations from $\mathrm{H}-6 \beta$ to $\mathrm{H}_{3}-22, \mathrm{H}_{3}-24, \mathrm{H}_{3}-25$, and $\mathrm{H}-7 \beta$, as well as from $\mathrm{H}_{3}-22$ to $\mathrm{H}_{3}-21$, confirming that they are cofacial. Since diagnostic NOESY correlations were observed from $\mathrm{H}-14$ to $\mathrm{H}_{3}-21, \mathrm{H}-12 \beta$, and $\mathrm{H}-12 \alpha$, the predominant conformation of 75 
is the one having gauche interactions of $\mathrm{H}-14$ with both $\mathrm{C}-21$ and $\mathrm{C}-12$, indicating the configuration of the hydroxyl group on C-14 [62].

Hasan et al. reported the isolations of salvidominicolide A (76), a manoyloxide-type sesterterpene with 6,23-pyran moiety and a side chain containing $\alpha$, $\beta$-unsaturated- $\gamma$ lactone (Figure 14) from S. dominica L. The structure of 76 was elucidated by $1 \mathrm{D}$ and 2D NMR spectral analysis and HRMS data. However, the stereochemistry of C-15 was not determined [64].

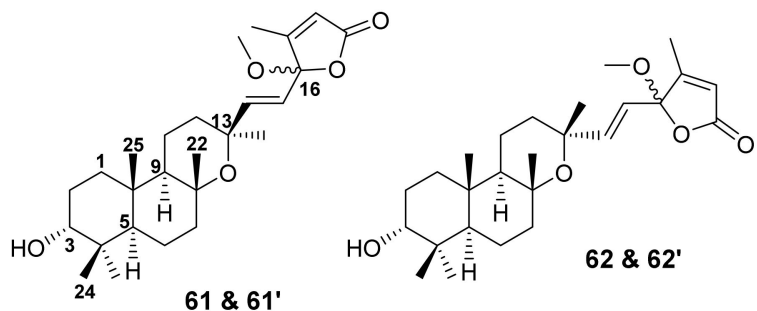

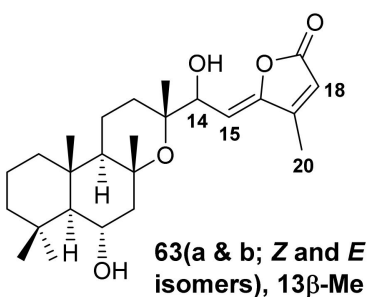

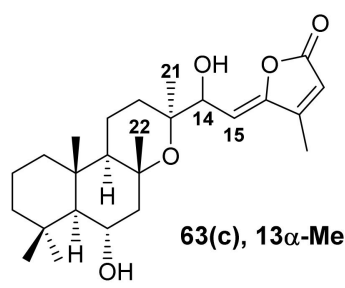

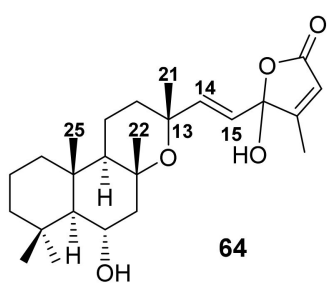<smiles>CC1=CC(=O)OC1(O)/C=C/C1CCC2(C)C(CC(O)[C@@]3(C)C(C)CCCC23)O1</smiles>

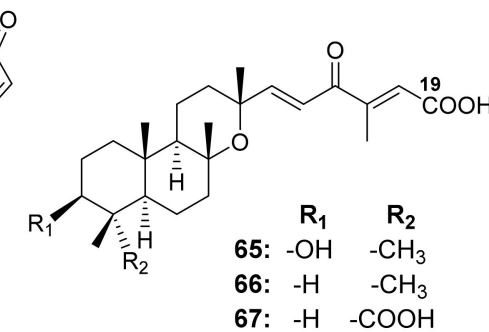

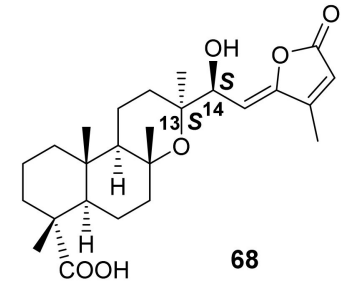

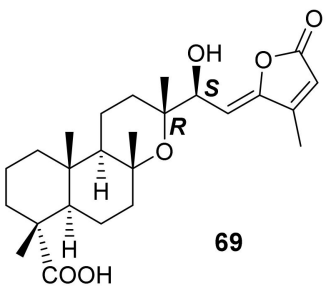

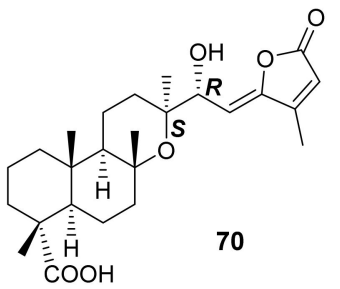

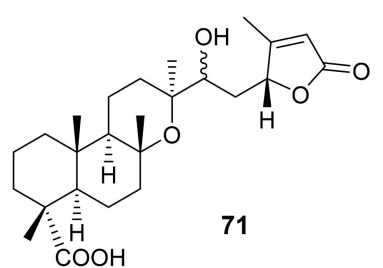

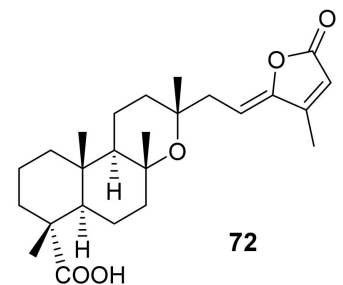

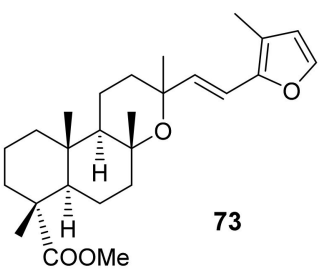

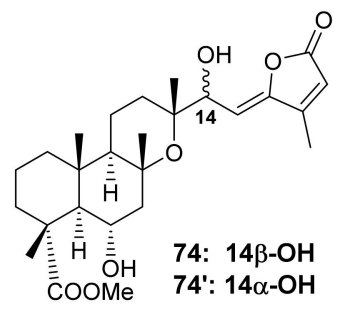

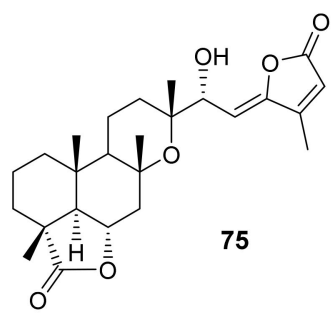

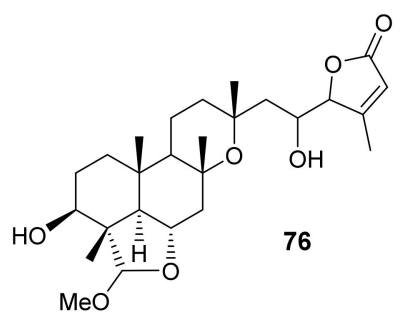

Figure 14. Structures of 61-76.

\subsection{Norsesterterpenes}

The $n$-hexane-insoluble portion of the $\mathrm{CH}_{2} \mathrm{Cl}_{2}$ extract of the aerial parts of $S$. tingitana also furnished a C-23 norsesterterpene (77) (Figure 15) whose planar structure was established by 1D and 2D NMR spectral analysis and HRMS data. The NOESY correlations from $\mathrm{H}-6$ to $\mathrm{H}_{3}-22, \mathrm{H}_{3}-24$, and $\mathrm{H}_{3}-25$, and from $\mathrm{H}-5$ to $\mathrm{H}-9$ indicated a trans-junction of the decalin ring system and a $\beta$-orientation of $\mathrm{H}-6$ and Me-24. However, the stereochemistry of $\mathrm{C}-16$ of the lactone ring was not determined. Consequently, the structure of $\mathbf{7 7}$ was established as (13E)-4 $\alpha, 6 \alpha, 8 \alpha$-trihydroxy-labd-13(14),17(18)-dien-16,19-olide. It is noteworthy mentioning that 77 is the first C-23 norsesterterpene from a Salvia species [52]. 


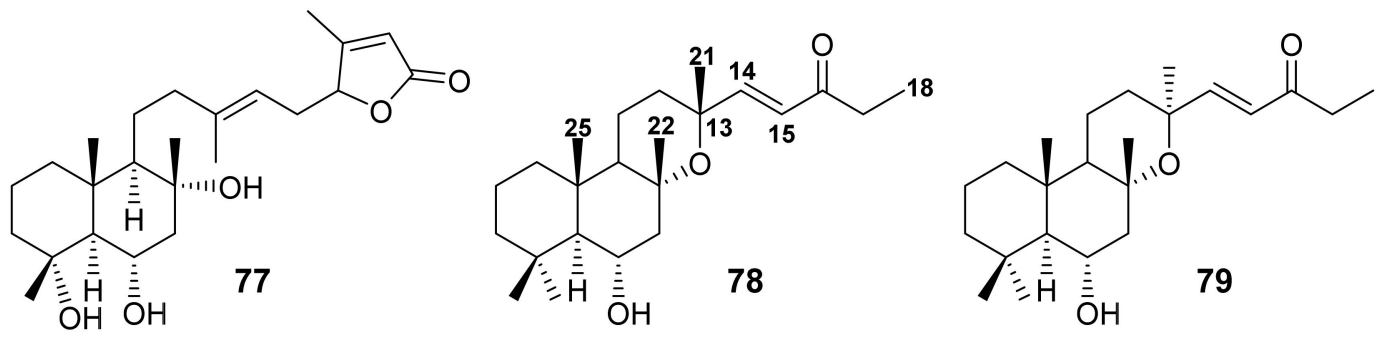

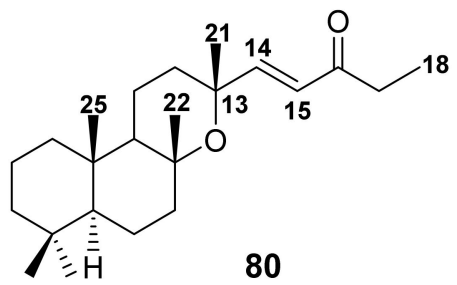<smiles>CCC(=O)/C=C/[C@@]1(C)CCC2[C@](C)(CC[C@]3(C)[C@@H](C)CCC[C@@]23C)O1</smiles>

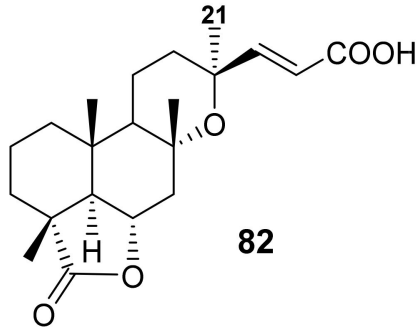

Figure 15. Structures of $77-82$.

In a continuing investigation of Turkish Salvia species, Topcu et al. reported the isolation of dinorsesterterpenes, yosgadensonol (78) and 13-epi-yosgadensonol (79) (Figure 15) from the acetone extract of the aerial parts of $S$. yosgadensis, collected from Central Turkey (near Sultanhani, Konya). The structures of $\mathbf{7 8}$ and 79 were elucidated by HREIMS, 1D and 2D-NMR spectral analysis. The 1D and 2D NMR spectra and the molecular formula of both compounds $\left(\mathrm{C}_{23} \mathrm{H}_{38} \mathrm{O}_{3}\right)$ identified them as 19,20-dinorsesterterpenes possessing the same tricyclic ring system as those of manoyloxide-type sesterterpenes but differ in the stereochemistry of C-13. The stereochemistry of C-16 in both compounds was determined by observing the NOE effects of Me-21 and Me-25 signals upon irradiation of Me-22 [69].

Another two dinorsesterterpenes, 6-dehydroxy-yosgadensonol (80) and 6-dehydroxy13-epi-yosgadensonol (81) (Figure 15), were reported form the acetone extract of the aerial parts of S. limbata C. A. Meyer. The structures of the compounds were elucidated by interpretation of the ${ }^{1} \mathrm{H}$ and ${ }^{13} \mathrm{C}$ NMR spectra and comparison of their NMR data with those of 78. The structure of $\mathbf{8 1}$ was established based on the slightly different proton chemical shift values of Me-21, Me-22 and Me-25 [70].

A C-17, C-18, C-19, and C-20 tetranorsesterterpene, (17,18,19,20-tetranor-13-epi-manoyloxide14-en-16-oic acid-23,6 $\alpha$-olide; 82) (Figure 15), was also isolated from the acetone extract of the aerial parts of $S$. sahendica. The structure of $\mathbf{8 2}$ was elucidated by HRESIMS and 1D and 2D NMR spectral analysis. The relative configuration at C-6 of the 23,6-lactone was determined as $R$ on the basis of the magnitude of the coupling constants of H- 6 as well as NOESY correlations from $\mathrm{H}-6$ to $\mathrm{H}_{3}-22, \mathrm{H}_{3}-24$, and $\mathrm{H}_{3}-25$, all $\beta$-oriented. On the other hand, Me-21 was established as $\alpha$-oriented due to a lack of NOE enhancement upon irradiation of Me-22. It is important to note that $\mathbf{8 2}$ is the first tetranorsesterterpene to have been reported from the genus Salvia [63].

\section{Dammarane Triterpenoids}

Dammarane-type triterpenoids are tetracyclic triterpenoids whose structural feature is characterized by a $6 / 6 / 6 / 5$ ring system with $\mathrm{H}-5 \alpha, \mathrm{H}-9 \alpha, \mathrm{H}-13 \beta$, three $\beta-\mathrm{CH}_{3}$ groups on $\mathrm{C}-4\left(\mathrm{CH}_{3}-28\right), \mathrm{C}-8\left(\mathrm{CH}_{3}-20\right), \mathrm{C}-10\left(\mathrm{CH}_{3}-19\right)$, one $\alpha-\mathrm{CH}_{3}$ group on $\mathrm{C}-14\left(\mathrm{CH}_{3}-30\right), \mathrm{C}-$ $17 \beta$-side chain, and $20 R$ or $S$ configuration (Figure 16) [71]. These compounds are widely distributed in various plant families such as Araliaceae (Aralia sp., Panax sp., Polyscias sp.), Meliaceae (Aglaia sp.), Scrophulariaceae (Bacopa sp.), Celastraceae (Celastrus sp.), Rhizophoraceae (Ceriops sp.), Arecaceae (Copernicia sp.), Oleaceae (Forsythia sp.), Cucurbitaceae (Gynostemma sp.), Anacardidaceae (Kageneckia sp., Myrica sp., Rhus sp.) and Lamiaceae (Salvia sp.) [72]. 


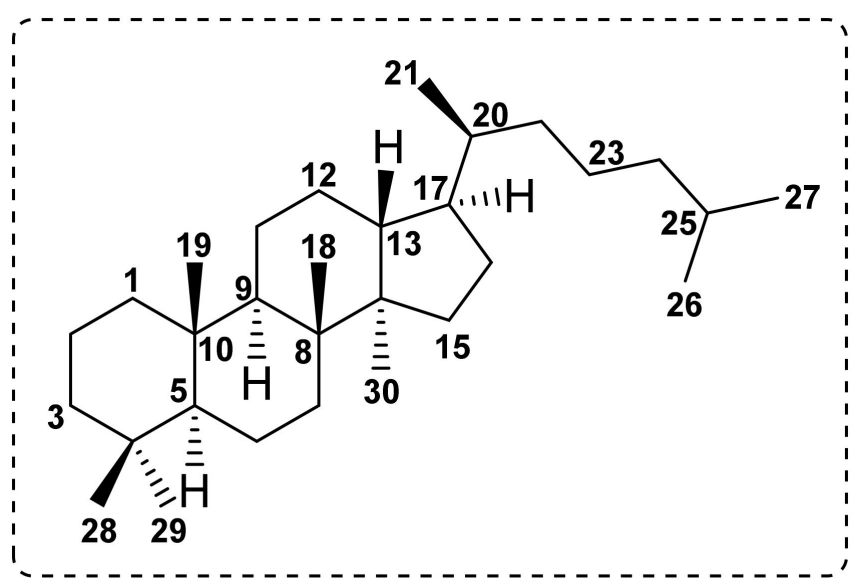

Figure 16. Basic carbon skeleton of dammarane-type triterpenoids.

Salvilymitol [(20S, 24R)-epoxydammarane-3 $\beta, 7 \alpha, 25$-triol] (83) and salvilymitone $(7 \beta, 25$ dihydroxy-(20S,24R)-epoxydammaran-3-one) (84) (Figure 17) were isolated from the acetone extract of the aerial parts of $S$. hierosolymitana Boiss., which was collected from the botanic garden of Palermo, Italy. The structures of both compounds were elucidated by electron impact mass spectrometry (EIMS) and analysis of ${ }^{1} \mathrm{H}$ and ${ }^{13} \mathrm{C}$ NMR spectra. By analysis of the ${ }^{13} \mathrm{C}$ NMR data, it was impossible to deduce the absolute configurations of the stereogenic carbons of the pyran ring in the side chain of $\mathbf{8 4}$ as $(20 S, 24 R)$ or $(20 R$, $24 S)$. However, the configurations of these carbons were conclusively determined as (20S, $24 R$ ) by a single-crystal X-ray crystallography of the $25,26,27$-trinor- $\gamma$-lactone derivative, a degradation products of $\mathbf{8 4}$ with Jones' reagent [73].

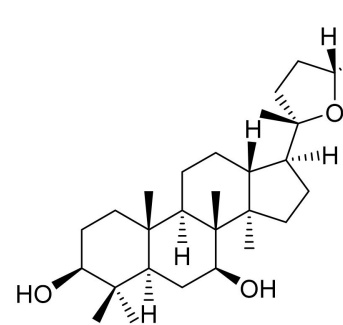

83

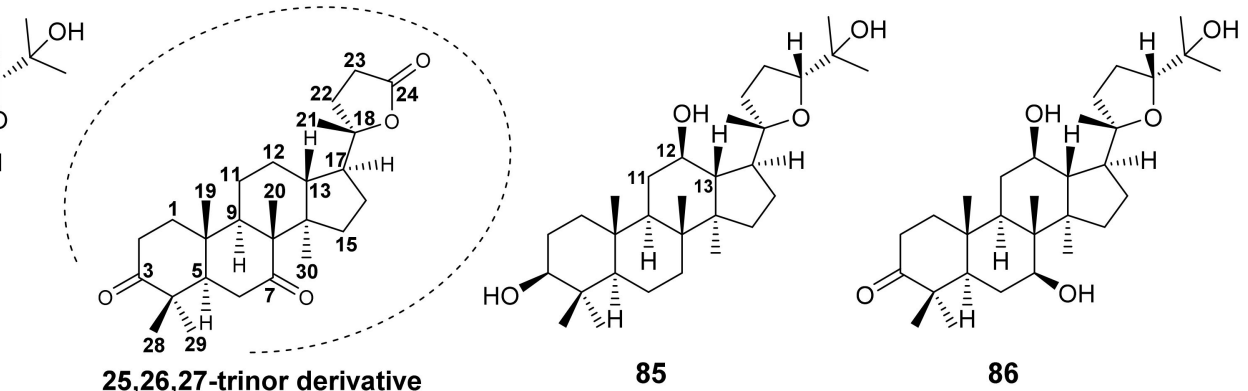

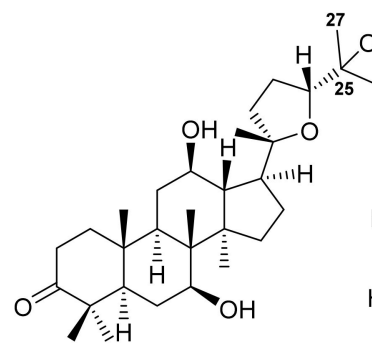

84

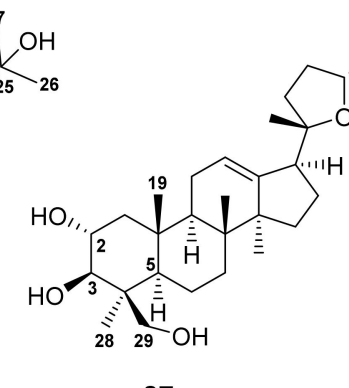

87

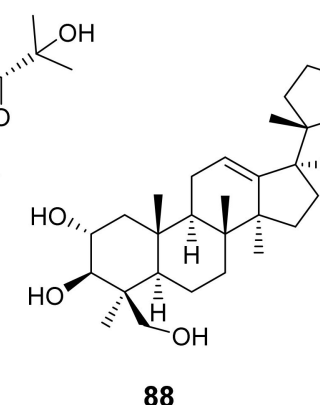

88<smiles>CCCC1CCC(=C(C)C)O1</smiles>

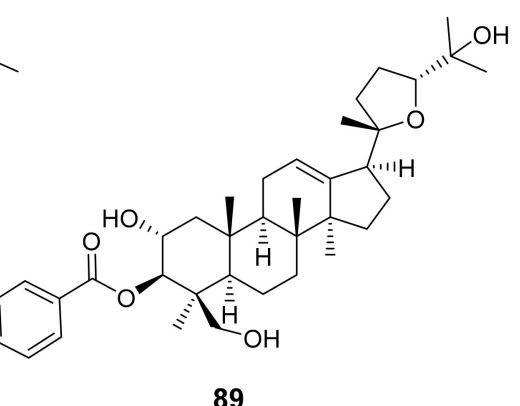

Figure 17. Structures of $83-89$.

Kolak et al. [74] reported the isolation of pixynol [(20S,24R)-epoxydammarane-3 $\beta, 12 \beta, 25-$ triol] (85) (Figure 17) from the acetone extract of roots of $S$. barrelieri Ettling, an endemic Salvia species to Algeria collected from Ammoucha-Setif district in Northeastern Algeria. Although 85 was first reported from a lichen Pyxine endochrysina NYL. [75], and later from the acetone extract of roots of S. bicolor, collected in Malaga, Spain [76], the absolute 
configurations of C-20 and C-24 had not been determined. However, Kolak et al. [74] were able to obtain a suitable crystal of $\mathbf{8 5}$ for X-ray analysis and have assigned a complete stereochemistry of $\mathbf{8 5}$.

In addition to 85, Valverde et al. also isolated (20S, 24R)-epoxydammar-12 $\beta$, 25-diol3-one (86) (Figure 17) from the acetone extract of roots of S. bicolor. The $\beta$-orientation of the hydroxyl group on C-12 was proposed by two large axial-axial coupling constants ( $c a$. $10.4 \mathrm{~Hz}$ ) of $\mathrm{H}-12$ with $\mathrm{H}-13$ and $\mathrm{H}-11 \beta$ while the absolute configurations of $\mathrm{C}-20$ and $\mathrm{C}-24$ were assigned by ${ }^{13} \mathrm{C}$ chemical shift values as well as comparison of the ${ }^{13} \mathrm{C}$ chemical shift values with those of the model compound [76].

The EtOAc-soluble fraction of the $\mathrm{MeOH}$ extract of the whole plant of S. santolinifolia Boiss., collected in Karachi, Pakistan, furnished three epoxydammarane triterpenes, santolins A-C (87-89) (Figure 17). The relative configurations at C-2, C-3, and C-4 of 87 were confirmed by the NOESY correlations from Me- $28 \alpha$ to $\mathrm{H}-3$ and $\mathrm{H}-5$, as well as from $\mathrm{Me}-19 \beta$ to $\mathrm{H}-2$, and $\mathrm{H}-29$. Thus, the structures of $\mathbf{8 7 - 8 9}$ were assigned as $(2 \alpha, 3 \beta, 20 S, 24 R)-$ 20,24-epoxydammar-12-ene-2,3,25,29-tetraol, ( $2 \alpha, 3 \beta, 20 S)$-20,24-epoxydammar-12,24-dien2,3,29-triol, and $(2 \alpha, 3 \beta, 20 S, 24 R)$-20,24-epoxy-2,25,29-trihydroxydammar-12-ene-3-yl 3,4hydroxybenzoate, respectively [77].

Esquivel et al. [78] reported the isolation of the undescribed trinordammarane triterpene, amblyol (90) and the previously reported amblyone (91) [79] (Figure 18) from the acetone extract of the aerial parts of $S$. aspera, collected in the state of Plueba, Mexico. Compound 90 was isolated as a C-24 epimeric mixture as revealed by duplicate signals for most of the carbons in the ${ }^{13} \mathrm{C}$ NMR spectrum. This hypothesis was corroborated by treatment of 90 with Jones reagent to give 91, as well as acetylation of 90 with $\mathrm{Ac}_{2} \mathrm{O}$ /pyridine in the presence of 4-dimethylaminopyridine to give two OAc-19. Finally, the stereostructure of one epimer was obtained by single-crystal X-ray crystallography.



90 (C-24 epimeric mixture: 90a/90b)

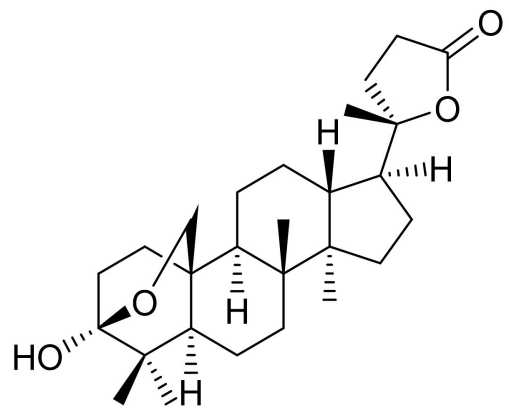

91

Figure 18. Structures of 90 and 91.

Recently, Hafez Ghoran et al. described the isolation of undescribed darmmarane-type triterpenoid saponins containing glucose moieties, russelliinosides A-C (92-94) (Figure 19), from the $\mathrm{CH}_{2} \mathrm{Cl}_{2}$ extract of the aerial parts $S$. Russellii Beneth., collected in Northwestern Iran. The relative configurations of 92-94 were established by NOESY correlations. Therefore, the structure of 92-94 were elucidated as 1-O-[ $\beta$-D-glucopyranosyl]-3 $\beta-O$-acetoxy-23hydroxydammar-12,24-diene, 1-O-[ $\beta$-D-glucopyranosyl]-3 $\beta, 23$-dihydroxydammar-12,24diene, and 1-O-[ $\beta$-D-glucopyranosyl]-3 $\beta-O$-acetoxy-23-[6-O-acetoxy- $\beta$-D-glucopyranosyl]dammar-12,24-diene, respectively. In all compounds, the glucose motifs were identified by a total correlation spectroscopy (TOCSY) correlations. Compounds 92-94 are the first $\Delta^{12,13}$ and C-20 saturated dammarane saponins [80]. 


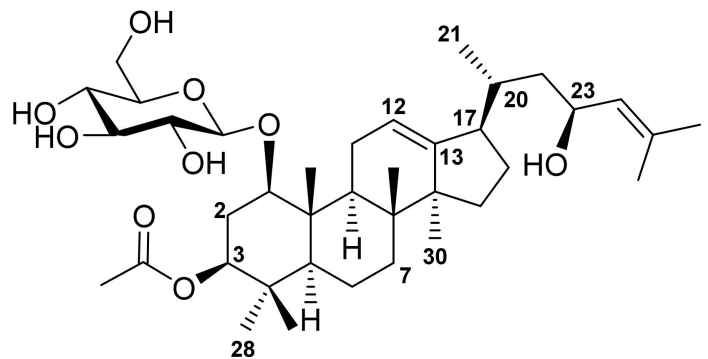

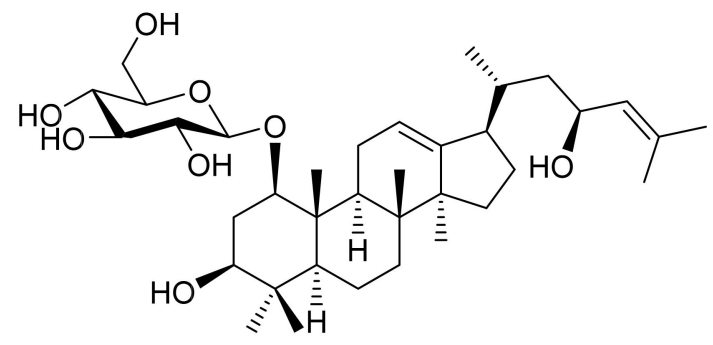

92

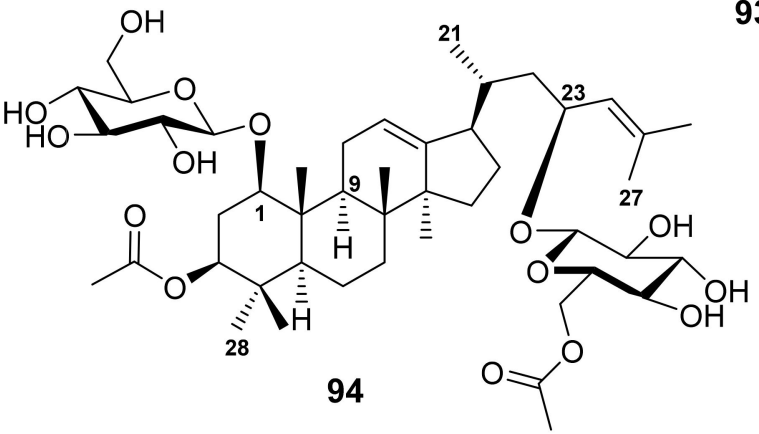

Figure 19. Structures of 92-94.

\section{Triterpenoids with Novel Skeleton}

Ahmad et al. described the isolation of salvadiones $A$ (95) and B (96), two $\mathrm{C}_{30^{-}}$ triterpenoids with a novel and rare carbon skeleton of five carbocycles, from the $n$-hexane soluble fraction of S. bucharica M. Pop, collected from Quetta, Baluchistan, Pakistan. The structures of 95 and 96 (Figure 20) were established by extensive analysis of 1D and 2D NMR spectra and were confirmed by single-crystal X-ray diffraction analysis [81]. Furthermore, the same research group has also reported the isolation of another triterpene of the same carbon skeleton, named salvadiol (97) (Figure 20) from the n-hexane soluble fraction of the same plant and whose structure was established by 1D and 2D NMR spectral analysis and single-crystal X-ray diffraction. The authors have proposed a biosynthetic pathway for 97 through a Diels-Alder type reaction of icetexone diterpene precursor with $\mathbf{X}$, which was derived from an autoxidation of the monoterpene myrcene (Figure 21) [82].

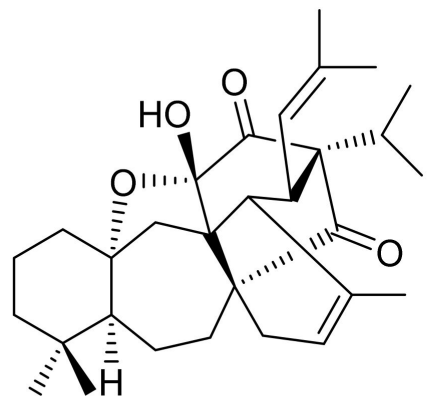

95

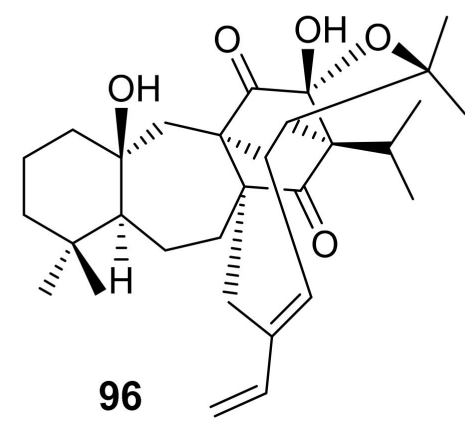

96



97

Figure 20. Structure of 95-97. 
<smiles>[X]C1(C)OC1C=CC(=C)C=CC1OC1(C)C</smiles>

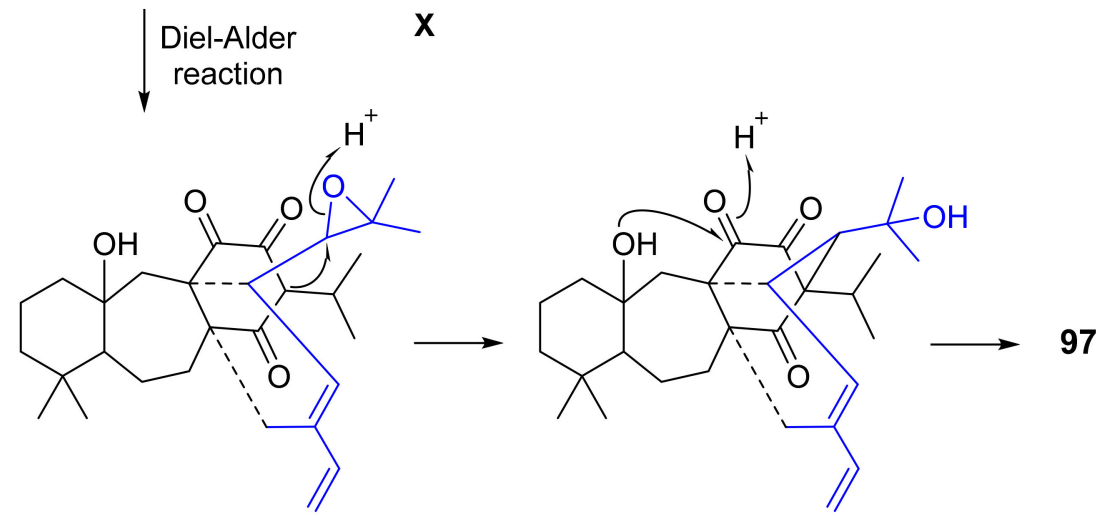

Figure 21. Proposed biogenesis of salvadiol (97) through Diel-Alder reaction of icetexone with autoxidation product of myrcene $(\mathbf{X})$.

The antiplasmodial $n$-hexane extract of the aerial parts of $S$. hydrangea DC. ex Benth., collected from the Koohin region in Qazvin Province, Iran, furnished salvadione C (98) and perovskone B (99) (Figure 22), two triterpenes of rare skeleton. The structures of $\mathbf{9 8}$ and $\mathbf{9 9}$ were elucidated by extensive analysis of 1D and 2D NMR spectra. The absolute configurations of the stereogenic carbons in $\mathbf{9 8}$ and $\mathbf{9 9}$ were established as $5 S, 8 R, 9 S, 10 S, 11 R, 13 R, 25 R$, $26 R, 27 S$ and $5 R, 8 R, 9 R, 10 R, 11 S, 12 R, 26 S$, respectively, by comparison of their experimental and calculated ECD spectra. Since the triterpene skeleton of $\mathbf{9 8}$ and $\mathbf{9 9}$ is the same as that of salvadiol (97), a similar biosynthetic route was proposed for 98 as shown in Figure 23 [83].

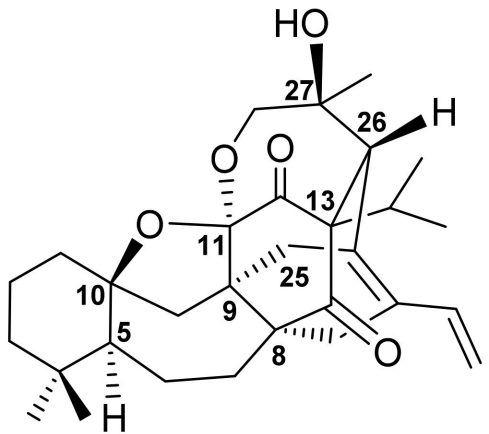

98

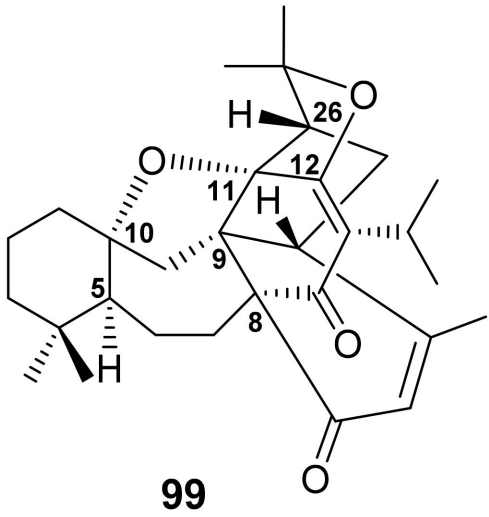

99

Figure 22. Structures of 98 and 99. 


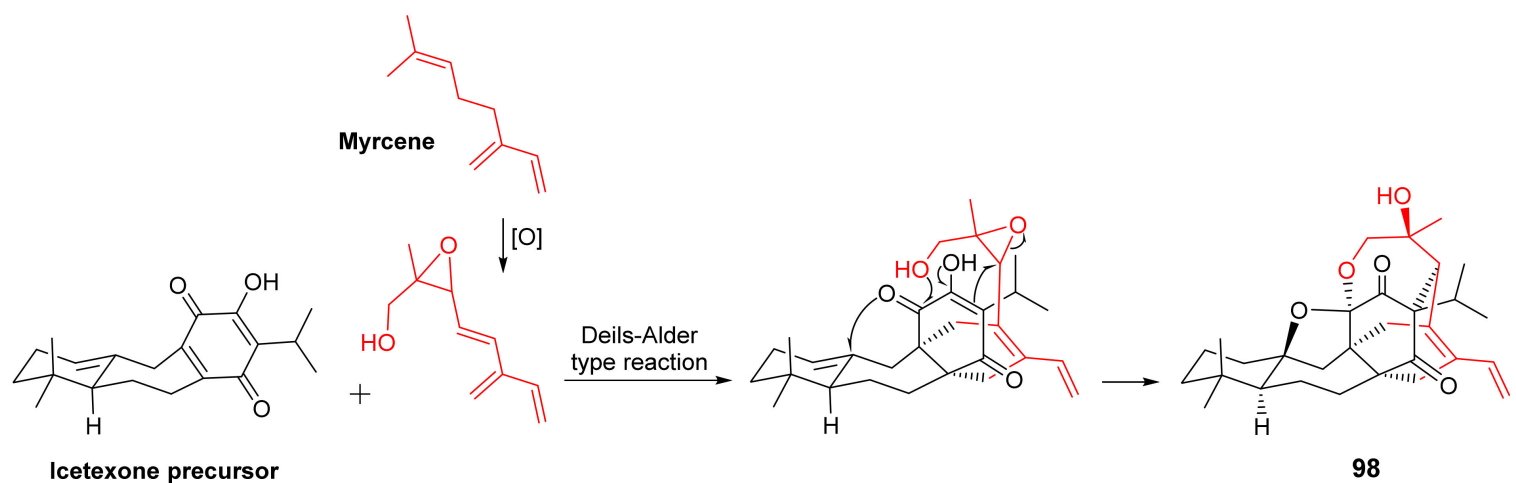

Figure 23. Proposed biosynthetic pathway for $\mathbf{9 8}$.

Further examination of the $n$-hexane extract of the aerial parts of $S$. hydrangea by the same research group led to the isolation of hydrangenone (100) (Figure 24), another heptacyclic triterpenoid with a $6 / 7 / 6 / 5 / 5$ ring system similar to that of 98 and 99 . The structure of $\mathbf{1 0 0}$ was elucidated by extensive analysis of $1 \mathrm{D}$ and 2D spectra. The relative configuration of $\mathbf{1 0 0}$ was established by NOESY correlations as well as by single-crystal Xray analysis while the absolute structure was established as $5 S, 8 R, 9 R, 10 S, 11 R, 22 R, 23 R, 25 R$ by comparison of the experimental and calculated ECD spectra [84].

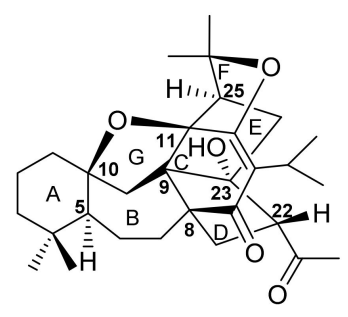

100

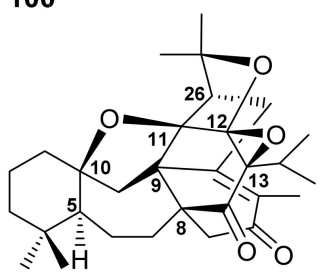

104

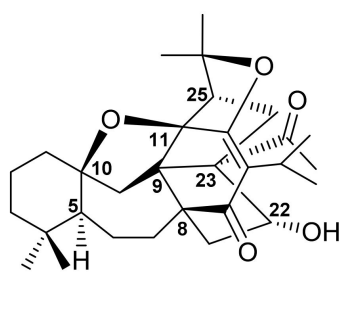

101

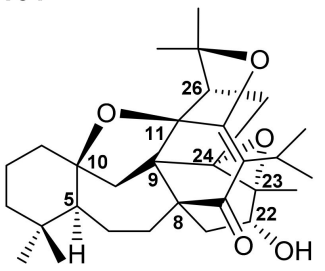

105

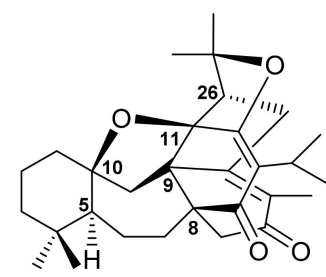

102

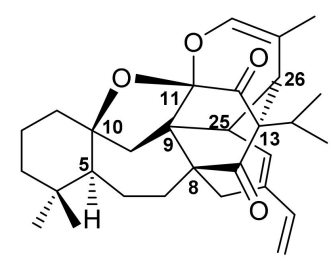

106

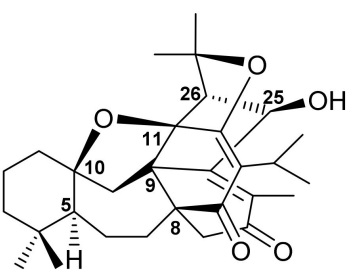

103

Figure 24. Structures of 100-106.

Continuation of a phytochemical investigation of the n-hexane extract of the aerial parts of $S$. hydrangea allowed Tabefam et al. to isolate further six unreported triterpenoids with rare skeleton, named hydrangenone B (101), pervoskones C-F (102-105) and salvadione D (106) (Figure 24), in addition to 95 (Figure 20). The structures of the isolated compounds were elucidated by comprehensive analysis of 1D and 2D NMR spectra and HRMS data. The absolute structures of all the compounds were determined by comparison of the calculated and experimental ECD spectra. In the case of 95, the absolute configurations of the stereogenic carbons were determined by single-crystal $\mathrm{X}$-ray diffraction analysis using $\mathrm{CuK} \alpha$ radiation. As a result, the absolute configurations of C-5, C-8, C-9, C-10, C-11, C-13, C-24 and C-25 are established as follows: $95(5 S, 8 R, 9 S, 10 S, 11 R, 13 R, 24 R, 25 R), 101$ $(5 S, 8 R, 9 R, 10 S, 11 R, 22 R, 23 S, 25 S), \mathbf{1 0 2}(5 S, 8 R, 9 S, 10 S, 11 R, 26 R), \mathbf{1 0 3}(5 S, 8 R, 9 S, 10 S, 11 R, 25 R, 26 R)$, $104(5 S, 8 R, 9 S, 10 S, 11 R, 12 R, 13 S, 26 R), 105$ (5S,8R,9R,10S,11R,22R,23R,24S,26R), and 106 (5S,8R, $9 S, 10 S, 11 R, 13 R, 25 R, 26 S)$. Additionally, a proposed biosynthetic pathway for $\mathbf{1 0 1}$ is shown in Figure 25 [85]. 


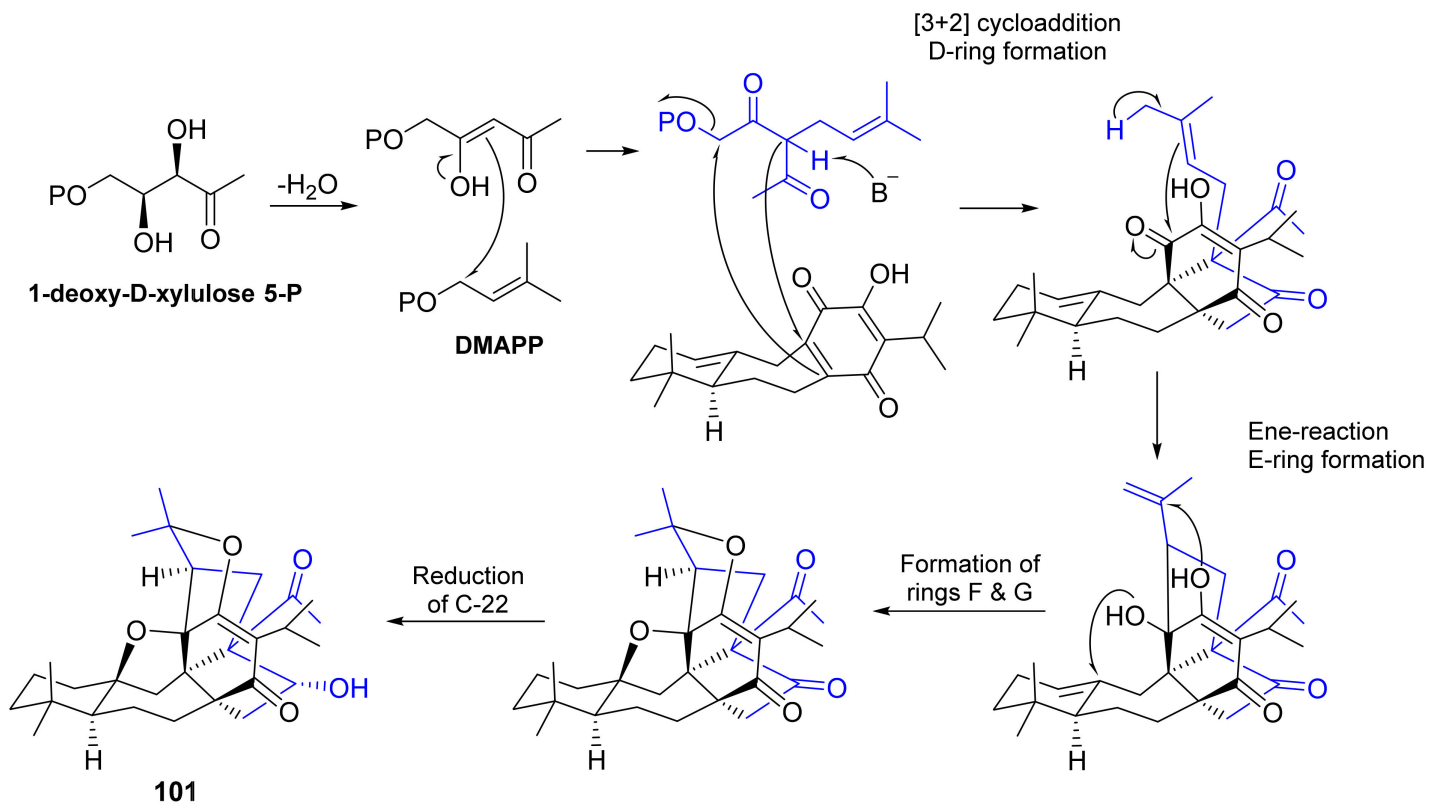

Figure 25. Proposed biosynthetic pathway for 101.

It is interesting to note that since this group of $\mathrm{C}_{30}$-terpenes is proposed to derive from the Diel-Alder reaction between icetexone-type diterpenoid and an autoxidation product of myrcene (a monoterpene), they are sometimes referred to as "isoprenoids" to distinguish them from normal triterpenoids, which are formed by direct cyclization of 2,3-oxidosqualene.

\section{Biological and Pharmacological Activities of Uncommon Terpenoids from Salvia Species}

\subsection{Antioxidant Activity}

As expected, a majority of terpenoid compounds do not possess relevant antioxidant activity. However, a few terpenoids from Salvia species were found to exhibit weak antioxidant properties. For example, rel-(5S,6S,7S,10R,12S,13R)-7-hydroxyapiana-8,14diene-11,16-dion-(22,6)-olide (4) (Figure 2) exhibited a weak activity in both DPPH assay and the oil stability index (OSI) with methyl linoleate [86]. Pixynol (84)(Figure 17) also exhibited a weak antioxidant activity when compared to butylated hydroxytoluene (BHT) and $\alpha$-tocopherol, in $\beta$-carotene-linoleic acid assay, followed by DPPH ${ }^{\bullet}, \mathrm{ABTS}^{\bullet+}$, and $\mathrm{O}_{2}{ }^{\bullet-}$ radicals, with $\mathrm{IC}_{50}$ values $>100 \mu \mathrm{g} / \mathrm{mL}$ [75].

\subsection{Antiviral Activity}

Since some 1,3-diketone-containing secondary metabolites are known as HIV-1 integrase inhibitors [87], Xu et al. tested 7 and 8 (Figure 3) for their cytopathic effects against HIV-1. Compound 7 displayed better anti-HIV-1 activity than 8, with half-maximal effective concentration $\left(E_{50}\right.$ ) values of 40.74 and $89.13 \mu \mathrm{g} / \mathrm{mL}$, respectively (selectivity index; SI of 2.19 and 1.78 , respectively). Interestingly, it was found that the more carbonyl groups the compounds have the weaker anti-HIV-1 effects the compounds exhibit [48].

\subsection{Cytotoxic Activity}

The in vitro cytotoxic activity assay showed that 21-26 (Figure 7) were inactive against three cancer cell lines viz. Hela ((cervical cancer), HEK293 (human embryonic kidney), and J774.A1 (mouse monocyte macrophage) at concentrations higher than $100 \mu \mathrm{M}[54,56]$.

A series of sesterterpenes, viz. 11 (Figure 5), 14, 15 (Figure 6), 21, 22 (Figure 7), 30-32 (Figure 8), 38 (Figure 9), 48 (Figure 10), 51-55, 60 (Figure 12), 65-67, 68-72, and 76 (Figure 14) isolated from $S$. dominica were tested for inhibitory activity against TTL, a promising target 
for new anticancer therapeutics that is involved in the tyrosination cycle of the C-terminal of tubulin in cancer cells, by Surface Plasmon Resonances (SPR) studies to obtain the kinetic and thermodynamic parameters of the ligand-protein complex formation. Interestingly, 18 out of the 24 compounds examined effectively interacted with TTL. Compounds 15, 51, 65, and 76 had the best pseudothermodynamic dissociation constants (KD) values of $9.3 \times 10^{-8}, 0.7 \times 10^{-8}, 7.2 \times 10^{-8}$, and $7.3 \times 10^{-8} \mathrm{M}$, respectively. On the other hand, 21, 22, 38, and 66, featuring one or two free hydroxyl groups at C-14 and C-15 in the side chain, were inactive. The presence of C-15/C-16 double bond, 23,6 $\alpha$-epoxy ring (in 38, 68, 69, and 71), and 23,6 $\alpha-\gamma$-lactone ring (in 30 and 70) obviously decreased the affinity for the enzyme, but a C-13/C-14 double bond and C-15 methylene group were essential for the activity. Furthermore, treatment of MCF-7 (human breast cancer) cells with the most active compound, 31 (with KD of $4.7 \times 10^{-8} \mathrm{M}$ from SPR assays) at a concentration of $100 \mu \mathrm{M}$ for 24 and $48 \mathrm{~h}$ and then analyzed by Western blot $\Delta-2$ tubulin levels, showed that 31 significantly penetrated the membrane and inhibited TTL inside the cancer cell. Thus, 31 could be considered a good lead for further drug developments to design a better drug because of its 10-fold higher activity than other compounds [54,56].

Compounds 33 (Figure 9), 41 (Figure 10), 74, and 75 (Figure 14), isolated from S. lachnocalyx, were evaluated against two human cancer-cell lines, HeLa and MCF-7, using the MTT ((3-(4,5-dimethylthiazol-2-yl)-2,5-diphenyltetrazolium bromide) assay. All sesterterpenes showed weak cytotoxicity, with $\mathrm{IC}_{50}$ values higher than $50 \mu \mathrm{M}$, when compared with paclitaxel (a positive control, $\mathrm{IC}_{50}$ values of 0.004 and $0.028 \mu \mathrm{M}$, respectively) [62].

The dammarane triterpenoid saponins 92-94 (Figure 19) were evaluated for their cytotoxicity against MCF-7 and A549 cell lines; however, only 92 and 93 exhibited cytotoxicity against MCF-7 $\left(\mathrm{IC}_{50}=7.1\right.$ and $30.7 \mu \mathrm{g} / \mathrm{mL}$, respectively) and $\mathrm{A} 549\left(\mathrm{IC}_{50}=33.9\right.$ and $69.4 \mu \mathrm{g} / \mathrm{mL}$, respectively). Analysis of structural features of these saponins suggested that the acetoxy group on C-3 increased the cytotoxicity, while C-23 glycosylation decreased the cytotoxicity [80].

\subsection{Antiparasitic Activity}

Antiplasmodial activity-guided fractionation of $S$. hydrangea by n-hexane, EtOAc, and $\mathrm{MeOH}$, revealed that the $\mathrm{n}$-hexane fraction was active against Plasmodium falciparum $\mathrm{K} 1$ and Trypanosoma brucei rhodesiense STIB900, with $\mathrm{IC}_{50}$ values of 3.2 and $18 \mu \mathrm{g} / \mathrm{mL}$, respectively. Among the isolated compounds from this active fraction, 98 and 99 (Figure 22) displayed potent antiplasmodial activity with $\mathrm{IC}_{50}$ values of 1.43 and $0.18 \mu \mathrm{M}$, respectively (SI of 86.2 and 69.6). On the other hand, 98 and 99 showed moderate potency against $T$. brucei rhodesiense STIB900 ( $\mathrm{IC}_{50}$ values of 4.33 and $15.92 \mu \mathrm{M}$, respectively) [83]. On the contrary, 100 (Figure 23) displayed moderate in vitro activity against $P$. falciparum $\mathrm{K} 1$, with $\mathrm{IC}_{50}=1.4 \mu \mathrm{M}, \mathrm{SI}=6$, cytotoxicity in rat myoblast (L6) cells. The $\mathrm{IC}_{50}$ of the positive control, artesunate, was $0.1 \mu \mathrm{M}$ [84]. Compounds 95 (Figure 20), 101-106 (Figure 24) were assayed for their in vitro inhibitory activity against some protozoan parasites including P. falciparum (NF54), T. brucei rhodesiense (STIB900) trypomastigotes, T. cruzi (Tulahuen C4) amastigotes, and Leishmania donovani (MHOM-ET-67/L82) amastigotes. Curiously, P. falciparum was found to be the most sensitive parasite to the tested compounds, with $\mathrm{IC}_{50}$ values ranging from $0.6 \mu \mathrm{M}$ (for 102) to $7.9 \mu \mathrm{M}$ (for 101). On the other hand, none of the tested compounds showed selective toxicity toward T. brucei rhodesiense and L. donovani (SI $\leq 2.4$ and SI $\leq 5.9$, respectively). Moreover, 102 and 103 were found to be the most active inhibitors against T. cruzi parasite with $\mathrm{IC}_{50}$ values of $3.5 \mu \mathrm{M}(\mathrm{SI}=10.7)$ and $3.8 \mu \mathrm{M}(\mathrm{SI}=3.6)$, respectively [85].

\subsection{Antibacterial Activity}

Compounds 9 (Figure 5), 12, 15 (Figure 6), 33, 38-40 (Figure 9), 41, 48 (Figure 10), 57-59 (Figure 12), 73 (Figure 14) and 77 (Figure 15) were investigated against 30 human pathogens, including 27 clinical strains and three isolates of marine origin. Interestingly, only $\mathbf{3 3}$ and $\mathbf{4 1}$ were active against Gram-positive bacteria, belonging to the Staphylococcus and Enterococcus genera. Compounds $\mathbf{3 3}$ and $\mathbf{4 1}$ were also found to inhibit the ATP production in purified 
mammalian rod outer segments, which is associated directly or indirectly with various human diseases [52].

In order to facilitate readers to quickly localize biological and pharmacological activities of these uncommon terpenoid compounds from the genus Salvia, the class of compounds (including compound names and numbers), plant sources, part used and biological/pharmacological activities are summarized in Table 1.

Table 1. Uncommon terpenoids from Salvia species and their biological/pharmacological activities.

\begin{tabular}{|c|c|c|c|c|}
\hline Compounds & Plant Species & Used Part & $\begin{array}{c}\text { Biological } \\
\text { Activity }\end{array}$ & Ref. \\
\hline \multicolumn{5}{|c|}{$\mathrm{C}_{23}$ terpenoids } \\
\hline $\begin{array}{l}\text { 14-hydroxy-7-methoxy-11,16-diketo-apian-8-en- } \\
\text { (22,6)-olide (1) }\end{array}$ & \multirow{2}{*}{ S. apiana Jeps } & \multirow{2}{*}{ Aerial Parts } & \multirow{2}{*}{-} & \multirow{2}{*}{ [45] } \\
\hline $\begin{array}{l}\text { 7-methoxy-11,16-diketo-apian-8,14-dien-(22,6)- } \\
\text { olide (2) }\end{array}$ & & & & \\
\hline $\begin{array}{l}\text { 13,14-dioxo-11-hydroxy-7-methoxy-hassane- } \\
\text { 8,11,15-trien-(22,6)-olide (3) }\end{array}$ & S. apiana Jeps & Aerial Parts & - & [46] \\
\hline $\begin{array}{l}\text { rel-(5S,6S,7S,10R,12S,13R)-7-hydroxyapiana-8,14- } \\
\text { diene-11,16-dion-(22,6)-olide (4) }\end{array}$ & \multirow{3}{*}{ S. officinalis L. } & \multirow{3}{*}{ Leaves } & $\begin{array}{l}\text { Weak antioxidant } \\
\text { activity }\end{array}$ & \multirow{3}{*}[47,86]{} \\
\hline $\begin{array}{l}\text { rel-(5S,6S,7R,10R,12S,13R)-7-hydroxyapiana- } \\
\text { 8,14-diene-11,16-dion-(22,6)-olide (5) }\end{array}$ & & & \multirow{2}{*}{ - } & \\
\hline $\begin{array}{l}\text { rel-(5S,6S,7S,10R,12R,13S)-7-hydroxyapiana-8,14- } \\
\text { diene-11,16-dion-(22,6)-olide (6) }\end{array}$ & & & & \\
\hline Przewalskin A (7) and its oxidation derivative (8) & $\begin{array}{l}\text { S. przewalskii } \\
\text { Maxim }\end{array}$ & Aerial parts & Anti-HIV-1 activity & [48] \\
\hline \multicolumn{5}{|c|}{ Sesterterpenoids } \\
\hline (13E)-labd-13(14),17(18)-dien-8 $8,16,19$-triol (9) & S. tingitana Etl., & Aerial parts & $\begin{array}{l}\text { Antibacterial and } \\
\text { ATP modulation } \\
\text { activity }\end{array}$ & [52] \\
\hline $\begin{array}{c}3 \alpha, 8 \alpha, 13,14 \text {-erythro-tetrahydroxy-labd-15,17-dien- } \\
\text { 16,19-olide (10) }\end{array}$ & $\begin{array}{l}\text { S. palaestina } \\
\text { Bentham }\end{array}$ & Aerial parts & - & [53] \\
\hline $\begin{array}{l}6 \alpha, 8 \alpha, 15(S) \text {-trihydroxy-labd-13(14),17-dien- } \\
\text { 16(S),19-olide (11) }\end{array}$ & S. dominica L. & Aerial parts & $\begin{array}{c}\text { Inhibition of } \\
\text { Tubulin Tyrosine } \\
\text { ligase }\end{array}$ & [54] \\
\hline $\begin{array}{c}(13 E)-8 \alpha, 23-d i h y d r o x y-l a b d-13(14), 17(18) \text {-dien- } \\
\text { 16,19-olide (12) }\end{array}$ & S. tingitana Etl. & Aerial parts & $\begin{array}{l}\text { Antibacterial and } \\
\text { ATP modulation } \\
\text { activity }\end{array}$ & [52] \\
\hline Salvisyriacolide (13) & S. syriaca L. & Aerial parts & - & {$[55]$} \\
\hline $\begin{array}{l}6 \alpha, 8 \alpha, 15(S), 23 \text {-tetrahydroxy-labd-13(14),17-dien- } \\
16(S), 19 \text {-olide (14) }\end{array}$ & \multirow{6}{*}{ S. dominica L. } & \multirow{6}{*}{ Aerial parts } & \multirow{6}{*}{$\begin{array}{c}\text { Inhibition of } \\
\text { Tubulin Tyrosine } \\
\text { ligase }\end{array}$} & \multirow{6}{*}{ [54] } \\
\hline $\begin{array}{c}6 \alpha, 8 \alpha, 23 \text {-trihydroxy-labd-13(14),17-dien- } \\
16(R), 19 \text {-olide }(\mathbf{1 5})\end{array}$ & & & & \\
\hline $\begin{array}{c}\text { 6x,15(S),23-trihydroxy-labd-8(22),13(14),17-trien- } \\
\text { 16(S),19-olide (16) }\end{array}$ & & & & \\
\hline $\begin{array}{c}6 \alpha, 8 \alpha, 23 \text {-trihydroxy-labd-13(14),15,17-trien- } \\
\text { 16,19-olide (17) }\end{array}$ & & & & \\
\hline $\begin{array}{l}6 \alpha, 8 \alpha, 23,14,15 \text {-threo-pentahydroxy-labd- } \\
\text { 13(21),17-dien-16,19-olide (18) }\end{array}$ & & & & \\
\hline $\begin{array}{c}6 \alpha, 8 \alpha, 23,14,15 \text {-erythro-pentahydroxy-labd- } \\
\text { 13(21),17-dien-16,19-olide (19) }\end{array}$ & & & & \\
\hline
\end{tabular}


Table 1. Cont.

\begin{tabular}{|c|c|c|c|c|}
\hline Compounds & Plant Species & Used Part & $\begin{array}{l}\text { Biological } \\
\text { Activity }\end{array}$ & Ref. \\
\hline $\begin{array}{c}6 \alpha, 8 \alpha, 13,23,14,15 \text {-threo-hexahydroxy-labd-17-en- } \\
\text { 16,19-olide (20) }\end{array}$ & S. dominica L. & Aerial parts & $\begin{array}{l}\text { Inhibition of } \\
\text { Tubulin Tyrosine } \\
\text { ligase }\end{array}$ & [56] \\
\hline $\begin{array}{l}6 \alpha, 8 \alpha, 15(S) \text {-trihydroxy-23-oxo-labd-13(14),17- } \\
\text { dien-16(S),19-olide (21) }\end{array}$ & \multirow{5}{*}{ S. dominica $\mathrm{L}$. } & \multirow{5}{*}{ Aerial parts } & \multirow{5}{*}{$\begin{array}{l}\text { Inhibition of } \\
\text { Tubulin Tyrosine } \\
\text { ligase }\end{array}$} & \multirow{5}{*}{ [54] } \\
\hline $\begin{array}{l}6 \alpha, 8 \alpha \text {-dihydroxy-23-oxo-labd-13(14),17-dien- } \\
16(R), 19 \text {-olide }(22)\end{array}$ & & & & \\
\hline 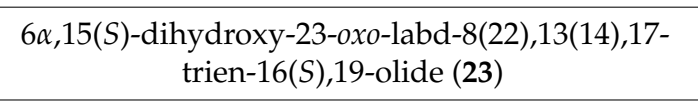 & & & & \\
\hline $\begin{array}{l}6 \alpha, 8 \alpha \text {-dihydroxy-23-oxo-labd-13(14),15,17-trien- } \\
\text { 16,19-olide (24) }\end{array}$ & & & & \\
\hline $\begin{array}{l}6 \alpha, 8 \alpha, 14,15 \text {-threo-tetrahydroxy-23-oxo-labd- } \\
\text { 13(21),17-dien-16,19-olide (25) }\end{array}$ & & & & \\
\hline $\begin{array}{c}6 \alpha, 8 \alpha, 13,14,15 \text {-threo-23-oxo-pentahydroxy-labd- } \\
\text { 17-en-16,19-olide (26) }\end{array}$ & S. dominica L. & Aerial parts & $\begin{array}{l}\text { Inhibition of } \\
\text { Tubulin Tyrosine } \\
\text { ligase }\end{array}$ & \\
\hline Salvimirzacolide (27) & $\begin{array}{l}\text { S. mirzayanii Rech. } \\
\text { and Esfandieri. }\end{array}$ & Aerial parts & - & [57] \\
\hline $\begin{array}{l}\text { 8 } \alpha, 13,14 \text {-threo-trihydroxy-labd-15,17-dien-16,19- } \\
\text { olide-23-oic acid (28) }\end{array}$ & \multirow{2}{*}{$\begin{array}{l}\text { S. palaestina } \\
\text { Bentham }\end{array}$} & \multirow{2}{*}{ Aerial parts } & \multirow{2}{*}{-} & \multirow{2}{*}{ [53] } \\
\hline $\begin{array}{c}8 \alpha, 13,14-e r y \text { thro-trihydroxy-labd-15,17-dien- } \\
\text { 16,19-olide-23-oic acid (29) }\end{array}$ & & & & \\
\hline $\begin{array}{c}6 \alpha, 8 \alpha, 15(S) \text {-trihydroxy-23-carboxy-labd- } \\
\text { 13(14),17-dien-16(S),19-olide (30) }\end{array}$ & \multirow{3}{*}{ S. dominica $\mathrm{L}$. } & \multirow{3}{*}{ Aerial parts } & \multirow{3}{*}{$\begin{array}{l}\text { Inhibition of } \\
\text { Tubulin Tyrosine } \\
\text { ligase }\end{array}$} & \multirow{3}{*}{ [54] } \\
\hline $\begin{array}{l}6 \alpha, 8 \alpha \text {-dihydroxy-23-carboxy-labd-13(14),17-dien- } \\
\text { 16,19-olide (31) }\end{array}$ & & & & \\
\hline $\begin{array}{l}6 \alpha, 8 \alpha \text {-dihydroxy-23-carboxy-labd-13(14),15,17- } \\
\text { trien-16,19-olide (32) }\end{array}$ & & & & \\
\hline \multirow{4}{*}{ Salvileucolide methyl ester (33) } & S. syriaca L. & Aerial parts & - & [55] \\
\hline & S. hypoleuca Benth. & Aerial parts & - & [58] \\
\hline & $\begin{array}{l}\text { S. sahendica Boiss \& } \\
\text { Buhse }\end{array}$ & Aerial parts & - & [59] \\
\hline & $\begin{array}{l}\text { S. lachnocalyx } \\
\text { Hedge }\end{array}$ & Aerial parts & Cytotoxic activity & [62] \\
\hline 14-hydroperoxy-13(21)-dehydro-SME (34) & \multirow{4}{*}{ S. hypoleuca Benth. } & \multirow{4}{*}{ Aerial parts } & \multirow{4}{*}{-} & \multirow{4}{*}{ [58] } \\
\hline 13-hydroperoxy-14-ene-SME (35) & & & & \\
\hline 13-epi-hydroperoxy-14-ene-SME (36) & & & & \\
\hline 14,17-cycloperoxy-13(21)-dehydro-SME (36) & & & & \\
\hline $\begin{array}{c}6 \alpha, 8 \alpha, 15(S) \text {-trihydroxy-23-carboxymethyl-labd- } \\
\text { 13(14),17-dien-16(S),19-olide (38) }\end{array}$ & S. dominica L. & Aerial parts & $\begin{array}{l}\text { Inhibition of } \\
\text { Tubulin Tyrosine } \\
\text { ligase }\end{array}$ & [54] \\
\hline $\begin{array}{c}(4 R, 5 R, 8 R, 9 R, 10 S, 16 R, 13 E)-8 \text {-hydroxy-23- } \\
\text { carboxymethyl-labd-13(14),17(18)-dien-16,19- } \\
\text { olide (39) }\end{array}$ & \multirow{2}{*}{ S. tingitana Etl. } & \multirow{2}{*}{ Aerial parts } & \multirow{2}{*}{$\begin{array}{l}\text { Antibacterial and } \\
\text { ATP modulation } \\
\text { activity }\end{array}$} & \multirow{2}{*}{ [52] } \\
\hline $\begin{array}{c}(4 R, 5 R, 6 S, 8 R, 9 R, 10 S, 15 S, 16 S, 13 E)-8,15- \\
\text { dihydroxy-23-carboxymethyl-labd-13(14),17(18)- } \\
\text { dien-16,19-olide (40) }\end{array}$ & & & & \\
\hline
\end{tabular}


Table 1. Cont.

\begin{tabular}{|c|c|c|c|c|}
\hline Compounds & Plant Species & Used Part & $\begin{array}{l}\text { Biological } \\
\text { Activity }\end{array}$ & Ref. \\
\hline \multirow{3}{*}{ Salvileucolide-6,23-lactone (41) } & S. hypoleuca Benth. & Aerial parts & - & [58] \\
\hline & $\begin{array}{l}\text { S. lachnocalyx } \\
\text { Hedge }\end{array}$ & Aerial parts & Cytotoxic activity & [62] \\
\hline & S. tingitana Etl. & Aerial parts & $\begin{array}{l}\text { Antibacterial and } \\
\text { ATP modulation } \\
\text { activity }\end{array}$ & [52] \\
\hline
\end{tabular}

15,16-dehydrosalvileucolide-6,23-lactone-transepoxide (42)

15,16-dehydrosalvileucolide-6,23-lactone-cisepoxide (43)

15,16-dehydrosalvileucolide-6,23-lactone-13,14-

S. hypoleuca Benth. Aerial parts bis-epi-trans-epoxide (44)

14-hydroperoxy-13(21)-dehydro-13,14-dihydrosalvileucolide-6,23-lactone (45)

\begin{tabular}{|c|c|c|c|c|}
\hline Salvileucolide (46) & S. tingitana Etl. & Aerial parts & $\begin{array}{l}\text { Antibacterial and } \\
\text { ATP modulation } \\
\text { activity }\end{array}$ & [52] \\
\hline Lachnocalyxolide B (47) & $\begin{array}{l}\text { S. lachnocalyx } \\
\text { Hedge }\end{array}$ & Aerial parts & Cytotoxic activity & {$[62]$} \\
\hline 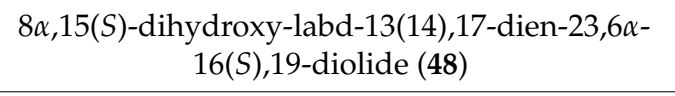 & \multirow{2}{*}{ S. dominica L. } & \multirow{2}{*}{ Aerial parts } & \multirow{2}{*}{$\begin{array}{l}\text { Inhibition of } \\
\text { Tubulin Tyrosine } \\
\text { ligase }\end{array}$} & \multirow{2}{*}{ [54] } \\
\hline $\begin{array}{c}8 \alpha \text {-hydroxy-labd-13(14),15,17-trien-6 } 6 \alpha, 23-16,19- \\
\text { diolide (49) }\end{array}$ & & & & \\
\hline $\begin{array}{l}8 \alpha \text {-hydroxy-13-hydroperoxylabd-14,17-dien- } \\
\text { 19,16;23,26 } \alpha \text {-diolide (50) }\end{array}$ & $\begin{array}{l}\text { S. sahendica Boiss \& } \\
\text { Buhse }\end{array}$ & Aerial parts & - & [63] \\
\hline $\begin{array}{l}\text { 23,6 } \alpha \text {-epoxy-labd-8,13(14),17-trien-16(R),19- } \\
\text { olide (51) }\end{array}$ & \multirow{6}{*}{ S. dominica L. } & \multirow{6}{*}{ Aerial parts } & \multirow{6}{*}{$\begin{array}{l}\text { Inhibition of } \\
\text { Tubulin Tyrosine } \\
\text { ligase }\end{array}$} & \multirow{6}{*}[54]{} \\
\hline $\begin{array}{l}\text { 15(S)-dihydroxy-23,6 } \alpha \text {-epoxy-labd-13(14),17- } \\
\text { dien-16(S),19-olide (52) }\end{array}$ & & & & \\
\hline $\begin{array}{c}8 \alpha, 15(S), 23 \alpha \text {-trihydroxy-23,6 } \alpha \text {-epoxy-labd- } \\
\text { 13(14),17-dien-16(S),19-olide }(53)\end{array}$ & & & & \\
\hline $\begin{array}{l}8 \alpha, 15(S) \text {-dihydroxy-23 } \alpha \text {-O-ethyl-23,6 } \alpha \text {-epoxy- } \\
\text { labd-13(14),17-dien-16(S),19-olide (54) }\end{array}$ & & & & \\
\hline $\begin{array}{l}8 \alpha \text {-hydroxy-23 } \alpha \text {-O-ethyl-23,6 } \alpha \text {-epoxy-labd- } \\
\text { 13(14),17-dien-16(R),19-olide (55) }\end{array}$ & & & & \\
\hline $\begin{array}{c}8 \alpha, 23 \text {-dihydroxy-23,6 } \alpha \text {-epoxy-labd-13(14),15,17- } \\
\text { trien-16,19-diolide (56) }\end{array}$ & & & & \\
\hline $\begin{array}{c}(4 R, 5 R, 6 S, 8 R, 9 R, 10 S, 16 R, 23 S, 13 E)-8,23- \\
\text { dihydroxy-23,6-epoxy-labd-13(14),17(18)-dien- } \\
\text { 16,19-olide (57) }\end{array}$ & \multirow{3}{*}{ S. tingitana Etl. } & \multirow{3}{*}{ Aerial parts } & \multirow{3}{*}{$\begin{array}{l}\text { Antibacterial and } \\
\text { ATP modulation } \\
\text { activity }\end{array}$} & \multirow{3}{*}[52]{} \\
\hline $\begin{array}{l}(13 E)-8 \alpha \text {-hydroxy-23 } \alpha \text {-O-methyl-23,6 } \alpha \text {-epoxy- } \\
\text { labd-13(14),17(18)-dien-16,19-olide (58) }\end{array}$ & & & & \\
\hline $\begin{array}{c}(4 R, 5 R, 6 S, 8 R, 9 R, 10 S, 15 S, 16 S, 23 S, 13 E)-8,15- \\
\text { dihydroxy-23-O-methyl-23,6-epoxy-labd- } \\
\text { 13(14),17(18)-dien-16,19-olide (59) }\end{array}$ & & & & \\
\hline Salvidominicolide B (60) & S. dominica L. & Whole parts & - & [64] \\
\hline 13-epi-salviaethiopisolide ( $\mathbf{6 1}$ and $\mathbf{6 \mathbf { 1 } ^ { \prime }}$ ) & \multirow{2}{*}{ S. aethiopis } & \multirow{2}{*}{ Aerial parts } & \multirow{2}{*}{-} & \multirow{2}{*}{ [65] } \\
\hline Salviaethiopisolide (62 and $\mathbf{6 2}{ }^{\prime}$ ) & & & & \\
\hline
\end{tabular}


Table 1. Cont.

\begin{tabular}{|c|c|c|c|c|}
\hline Compounds & Plant Species & Used Part & $\begin{array}{l}\text { Biological } \\
\text { Activity }\end{array}$ & Ref. \\
\hline 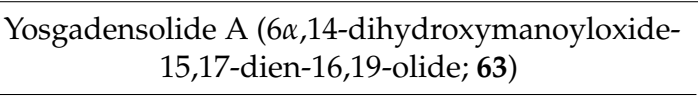 & \multirow{2}{*}{$\begin{array}{l}\text { S. yosgadensis Freyn } \\
\text { et Bornm. }\end{array}$} & \multirow{2}{*}{ Aerial parts } & \multirow{2}{*}{-} & \multirow{2}{*}[66]{} \\
\hline $\begin{array}{c}\text { yosgadensolide B }(6 \alpha, 16 \text {-dihydroxymanoyloxide- } \\
\text { 14,17-dien-16,19-olide; } 64)\end{array}$ & & & & \\
\hline $\begin{array}{l}\text { 3 } \beta \text {-hydroxymanoyloxide-14(E),17-dien-16-oxo- } \\
\text { 19-oic acid (65) }\end{array}$ & \multirow{3}{*}{ S. aethiopis L. } & \multirow{3}{*}{ Aerial parts } & \multirow{3}{*}{-} & \multirow{3}{*}{ [67] } \\
\hline $\begin{array}{l}\text { Hydroxymanoyloxide-14,17-dien-16-oxo-19- } \\
\text { oic acid (66) }\end{array}$ & & & & \\
\hline $\begin{array}{l}\text { Hydroxymanoyloxide-14,17-dien-16-oxo-19,23- } \\
\text { dioic acid (67) }\end{array}$ & & & & \\
\hline $\begin{array}{c}(4 R, 5 R, 8 R, 9 R, 10 S, 13 S, 14 S)-14- \\
\text { hydroxymanoyloxide-15,17-dien-15(Z)-16,19- } \\
\text { olide }(68)\end{array}$ & \multirow{5}{*}{$\begin{array}{l}\text { S. mirzayanii Rech. } \\
\text { and Esfandieri. }\end{array}$} & \multirow{5}{*}{ Aerial parts } & \multirow{5}{*}{-} & \multirow{5}{*}[68]{} \\
\hline $\begin{array}{c}(4 R, 5 R, 8 R, 9 R, 10 S, 13 R, 14 S)-14- \\
\text { hydroxymanoyloxide-15,17-dien-15(Z)-16,19- } \\
\text { olide (69) }\end{array}$ & & & & \\
\hline $\begin{array}{c}(4 R, 5 R, 8 R, 9 R, 10 S, 13 S, 14 R)-14- \\
\text { hydroxymanoyloxide-15,17-dien-15(Z)-16,19- } \\
\text { olide (70) }\end{array}$ & & & & \\
\hline $\begin{array}{c}(4 R, 5 R, 8 R, 9 R, 10 S, 13 R, 16 R)-14- \\
\text { hydroxymanoyloxide-17-en-16,19-olide (71) }\end{array}$ & & & & \\
\hline $\begin{array}{c}(4 R, 5 R, 8 R, 9 R, 10 S, 13 R) \text {-manoyloxide-15,17-dien- } \\
\text { 15(Z)-16,19-olide (72) }\end{array}$ & & & & \\
\hline $\begin{array}{l}\text { (14E)-methylmanoyloside-14,16,18-trien-16,19- } \\
\text { oxide-23-carboxilate (73) }\end{array}$ & S. tingitana Etl. & Aerial parts & $\begin{array}{l}\text { Antibacterial and } \\
\text { ATP modulation } \\
\text { activity }\end{array}$ & [52] \\
\hline Lachnocalyxolide A (74) & \multirow{2}{*}{$\begin{array}{l}\text { S. lachnocalyx } \\
\text { Hedge }\end{array}$} & \multirow{2}{*}{ Aerial parts } & \multirow{2}{*}{ Cytotoxic activity } & \multirow{2}{*}[62]{} \\
\hline Lachnocalyxolide C (75) & & & & \\
\hline Salvidominicolide A (76) & S. dominica L. & Whole parts & - & [64] \\
\hline $\begin{array}{l}(13 E)-4 \alpha, 6 \alpha, 8 \alpha \text {-trihydroxy-labd-13(14),17(18)- } \\
\text { dien-16,19-olide (77) }\end{array}$ & S. tingitana Etl. & Aerial parts & $\begin{array}{l}\text { Antibacterial and } \\
\text { ATP modulation } \\
\text { activity }\end{array}$ & [52] \\
\hline Yosgadensonol (78) & \multirow{2}{*}{$\begin{array}{l}\text { S. yosgadensis Freyn } \\
\text { et Bornm. }\end{array}$} & \multirow{2}{*}{ Aerial parts } & \multirow{2}{*}{-} & \multirow{2}{*}[69]{} \\
\hline 13-epi-yosgadensonol (79) & & & & \\
\hline 6-dehydroxy-yosgadensonol (80) & \multirow{2}{*}{$\begin{array}{l}\text { S. limbata C. A. } \\
\text { Meyer }\end{array}$} & \multirow{2}{*}{ Aerial parts } & \multirow{2}{*}{-} & \multirow{2}{*}[70]{} \\
\hline 6-dehydroxy-13-epi-yosgadensonol (81) & & & & \\
\hline $\begin{array}{l}(17,18,19,20 \text {-tetranor-13-epi-manoyloxide-14-en- } \\
\text { 16-oic acid-23,6 } \alpha \text {-olide; } 82)\end{array}$ & $\begin{array}{l}\text { S. sahendica Boiss \& } \\
\text { Buhse }\end{array}$ & Aerial parts & - & [63] \\
\hline \multicolumn{5}{|c|}{ Dammarane triterpenoids } \\
\hline Salvilymitol (83) & \multirow{2}{*}{$\begin{array}{l}\text { S. hierosolymitana } \\
\text { Boiss. }\end{array}$} & \multirow{2}{*}{ Aerial parts } & \multirow{2}{*}{-} & \multirow{2}{*}[73]{} \\
\hline Salvilymitone (84) & & & & \\
\hline Pixynol (85) & S. barrelieri Ettling & Roots & $\begin{array}{l}\text { Weak antioxidant } \\
\text { activity }\end{array}$ & {$[74,75]$} \\
\hline$(20 S, 24 R)$-epoxydammar-12 $\beta, 25$-diol-3-one (86) & S. bicolor & Whole parts & - & [76] \\
\hline Santolin A (87) & \multirow{3}{*}{ S. santolinifolia Boiss. } & \multirow{3}{*}{ Whole parts } & \multirow{3}{*}{-} & \\
\hline Santolin B (88) & & & & {$[77]$} \\
\hline Santolin C (89) & & & & \\
\hline
\end{tabular}


Table 1. Cont.

\begin{tabular}{|c|c|c|c|c|}
\hline Compounds & Plant Species & Used Part & $\begin{array}{l}\text { Biological } \\
\text { Activity }\end{array}$ & Ref. \\
\hline Amblyol (90) & \multirow{2}{*}{ S. aspera M. et G. } & \multirow{2}{*}{ Aerial parts } & \multirow{2}{*}{-} & \multirow[b]{2}{*}[79]{} \\
\hline Amblyone (91) & & & & \\
\hline Russelliinoside A (92) & \multirow{3}{*}{ S. Russellii Beneth. } & \multirow{3}{*}{ Aerial parts } & \multirow{3}{*}{ Cytotoxic activity } & \multirow{3}{*}{ [80] } \\
\hline Russelliinoside B (93) & & & & \\
\hline Russelliinoside C (94) & & & & \\
\hline & \multicolumn{2}{|c|}{ Uncommon triterpenoids } & & \\
\hline Salvadione A (95) & \multirow{2}{*}{ S. bucharica M. Pop } & \multirow{2}{*}{ Aerial parts } & \multirow{2}{*}{-} & \multirow{2}{*}{ [81] } \\
\hline Salvadione B (96) & & & & \\
\hline Salvadiol (97) & S. bucharica M. Pop & Aerial parts & - & {$[82]$} \\
\hline Salvadione C (98) & \multirow{2}{*}{$\begin{array}{l}\text { S. hydrangea DC. ex. } \\
\text { Benth. }\end{array}$} & \multirow{2}{*}{ Aerial parts } & \multirow{2}{*}{$\begin{array}{l}\text { Antiparasitic } \\
\text { activity }\end{array}$} & \multirow{2}{*}{ [83] } \\
\hline Perovskone B (99) & & & & \\
\hline Hydrangenone (100) & $\begin{array}{l}\text { S. hydrangea DC. ex. } \\
\text { Benth. }\end{array}$ & Aerial parts & $\begin{array}{c}\text { Antiparasitic } \\
\text { activity }\end{array}$ & [84] \\
\hline Salvadione A (95) & \multirow{7}{*}{$\begin{array}{l}\text { S. hydrangea DC. ex. } \\
\text { Benth. }\end{array}$} & \multirow{7}{*}{ Aerial parts } & \multirow{7}{*}{$\begin{array}{l}\text { Antiparasitic } \\
\text { activity }\end{array}$} & \multirow{7}{*}[85]{} \\
\hline Hydrangenone B (101) & & & & \\
\hline Pervoskones C (102) & & & & \\
\hline Pervoskones D (103) & & & & \\
\hline Pervoskones E (104) & & & & \\
\hline Pervoskones F (105) & & & & \\
\hline Salvadione D (106) & & & & \\
\hline
\end{tabular}

\section{Conclusions and Future Perspectives}

The outlined examples highlight that plants of the genus Salvia are an interesting source for compounds with novel and unique scaffolds for further development as drug leads. From the initial breakthrough, the structures of uncommon Salvia terpenoids, especially the dammarane-type triterpenoids and sesterterpenoids, have not been thoroughly investigated. Although this review covers 106 terpenoids from members of the genus Salvia and some proposed biosynthetic pathways, biological and pharmacological activities have been less considered due to the shortcoming in information regarding the biological properties obtained from previous studies. The biosynthetic pathways for apiananes, hassananes, and dammaranes indicate that secondary metabolite production can be species-specific. Owing to huge potential of underexplored bioactivities, terpenoids from Salvia species can certainly be explored as a promising group of secondary metabolites for applications in the pharmaceutical, cosmeceutical and agro industries. On the other hand, due to a lack of reliable technology, the relative and absolute configurations of many terpenoids studies in the 1970s and 1980s are still undetermined and can be a challenging task for researchers in this field. Therefore, a revisit of the stereochemistry of these compounds by modern chiroptical methods is another important aspect to be addressed. All in all, this review can provide an insight for researchers who look for bioactive secondary metabolites from Salvia plants with unique and rare scaffolds.

Author Contributions: Conceptualization, S.H.G. and A.K.; literature search, F.T.; design, drawing of structures, and preparation of the draft of the manuscript, S.H.G. and F.T.; comments and suggestions, M.T., N.S. and A.A.M.; review and edit the manuscript, A.K. All authors have read and agreed to the published version of the manuscript. 
Funding: This work is partially supported by national funds through FCT—Foundation for Science and Technology with the scope of UIDB/04423/2020 and UIDP/04423/2020.

Institutional Review Board Statement: Not applicable.

Informed Consent Statement: Not applicable.

Data Availability Statement: Data sharing is not applicable to this article.

Acknowledgments: The authors thank Kurdistan University and Instituto de Ciências Biomédicas Abel Salazar of the University of Porto for logistical supports, and Seyed Abdulmajid Ayatollahi from Phytochemistry Research Center, Shahid Beheshti University of Medical Sciences, is kindly thanked for providing the helpful advice. Mehdi Zare, a plant taxonomist, is also appreciated for providing the original photos of the Salvia species.

Conflicts of Interest: The authors declare no conflict of interest.

\section{References}

1. Drew, B.; González-Gallegos, J.G.; Xiang, C.; Kriebel, R.; Drummond, C.; Walker, J.; Sytsma, K. Salvia united: The greatest good for the greatest number. Taxon 2017, 66, 133-145. [CrossRef]

2. Wu, Y.B.; Ni, Z.Y.; Shi, Q.W.; Dong, M.; Kiyota, H.; Gu, Y.C.; Cong, B. Constituents from Salvia species and their biological activities. Chem. Rev. 2012, 112, 5967-6026. [CrossRef] [PubMed]

3. Will, M.; Claßen-Bockhoff, R. Time to split Salvia s.l. (Lamiaceae)—New insights from Old World Salvia phylogeny. Mol. Phylogenet. Evol. 2017, 109, 33-58. [CrossRef] [PubMed]

4. Jamzad, Z. Lamiaceae. In Flora of Iran, 1st ed.; Assadi, M., Maassoumi, A.A., Mozaffarian, V., Eds.; Research Institute of Forests and Rangelands Publications Research Institute of Forests and Rangelands Publications: Tehran, Iran, 2012; Volume 76, pp. 948-950.

5. Li, M.; Li, Q.; Zhang, C.; Zhang, N.; Cui, Z.; Huang, L.; Xiao, P. An ethnopharmacological investigation of medicinal Salvia plants (Lamiaceae) in China. Acta Pharm. Sin. B 2013, 3, 273-280. [CrossRef]

6. Kamatou, G.; Makunga, N.; Ramogola, W.; Viljoen, A. South African Salvia species: A review of biological activities and phytochemistry. J. Ethnopharmacol. 2008, 119, 664-672. [CrossRef] [PubMed]

7. Lopresti, A.L. Salvia (Sage): A review of its potential cognitive-enhancing and protective effects. Drugs RED 2016, 17, 53-64. [CrossRef]

8. Sharifi-Rad, M.; Ozcelik, B.; Altın, G.; Daşkaya-Dikmen, C.; Martorell, M.; Ramírez-Alarcón, K.; Alarcón-Zapata, P.; Morais-Braga, M.F.B.; Carneiro, J.N.; Leal, A.L.A.B.; et al. Salvia spp. plants-from farm to food applications and phytopharmacotherapy. Trends Food Sci. Technol. 2018, 80, 242-263. [CrossRef]

9. Valdivia-López, M.; Tecante, A. Chia (Salvia hispanica): A Review of Native Mexican Seed and its Nutritional and Functional Properties. In Advances in Food and Nutrition Research; Elsevier: Amsterdam, The Netherlands, 2015; Volume 75, pp. 53-75. [CrossRef]

10. Zhang, X.Z.; Qian, S.S.; Zhang, Y.J.; Wang, R.Q. Salvia miltiorrhiza: A source for anti-Alzheimer's disease drugs. Pharm. Biol. 2015, 54, 18-24. [CrossRef]

11. Akhondzadeh, S.; Noroozian, M.; Mohammadi, M.; Ohadinia, S.; Jamshidi, A.H.; Khani, M. Salvia officinalis extract in the treatment of patients with mild to moderate Alzheimer's disease: A double blind, randomized and placebo-controlled trial. J. Clin. Pharm. Ther. 2003, 28, 53-59. [CrossRef]

12. Moss, L.; Rouse, M.; Wesnes, K.; Moss, M. Differential effects of the aromas of Salvia species on memory and mood. Hum. Psychopharmacol. Clin. Exp. 2010, 25, 388-396. [CrossRef]

13. Seol, G.H.; Shim, H.S.; Kim, P.-J.; Moon, H.K.; Lee, K.H.; Shim, I.; Suh, S.H.; Min, S.S. Antidepressant-like effect of Salvia sclarea is explained by modulation of dopamine activities in rats. J. Ethnopharmacol. 2010, 130, 187-190. [CrossRef] [PubMed]

14. Mora, S.; Millán, R.; Lungenstrass, H.; Díaz-Véliz, G.; Morán, J.; Herrera-Ruiz, M.; Tortoriello, J. The hydroalcoholic extract of Salvia elegans induces anxiolytic- and antidepressant-like effects in rats. J. Ethnopharmacol. 2006, 106, 76-81. [CrossRef] [PubMed]

15. Vuksan, V.; Whitham, D.; Sievenpiper, J.L.; Jenkins, A.L.; Rogovik, A.L.; Bazinet, R.P.; Vidgen, E.; Hanna, A. Supplementation of conventional therapy with the novel grain Salba (Salvia hispanica L.) improves major and emerging cardiovascular risk factors in type 2 diabetes. Diabetes Care 2007, 30, 2804-2810. [CrossRef] [PubMed]

16. Solares-Pascasio, J.; Ceballos, G.; Calzada, F.; Barbosa, E.; Velazquez, C. Antihyperglycemic and lipid profile effects of Salvia amarissima Ortega on streptozocin-induced type 2 diabetic mice. Molecules 2021, 26, 947. [CrossRef] [PubMed]

17. Kumar, P.M.; Sasmal, D.; Mazumder, P.M. The antihyperglycemic effect of aerial parts of Salvia splendens (scarlet sage) in streptozotocin-induced diabetic-rats. Pharmacogn. Res. 2010, 2, 190-194. [CrossRef]

18. Zarei, A.; Vaezi, G.; Malekirad, A.A.; Abdollahi, M. Hypoglycemic and hypolipidemic activities of Salvia hydrangea in streptozotocin-induced diabetes in rats. Iran. J. Basic Med. Sci. 2015, 18, 417-422. [CrossRef]

19. Alfieri, A.; Maione, F.; Bisio, A.; Romussi, G.; Mascolo, N.; Cicala, C. Effect of a diterpenoid from Salvia cinnabarina on arterial blood pressure in rats. Phytotherapy Res. 2007, 21, 690-692. [CrossRef] 
20. Fernando, M.-P.; Alberto, H.-L.; Guadalupe, V.-D.M.; Agustina, C.-M.; Fernando, N.-G.; Eva, A.-H.; Hermelinda, S.-C.; Eva, G.-T.M. Neo-clerodane diterpenic influence in the antinociceptive and anti-inflammatory properties of Salvia circinnata Cav. J. Ethnopharmacol. 2020, 268, 113550. [CrossRef]

21. Brindisi, M.; Bouzidi, C.; Frattaruolo, L.; Loizzo, M.R.; Tundis, R.; Dugay, A.; Deguin, B.; Cappello, A.R.; Cappello, M.S. Chemical profile, antioxidant, anti-inflammatory, and anti-cancer effects of Italian Salvia rosmarinus Spenn. methanol leaves extracts. Antioxidants 2020, 9, 826. [CrossRef]

22. Jang, H.-J.; Lee, S.; Lee, S.J.; Lim, H.-J.; Jung, K.; Kim, Y.H.; Lee, S.W.; Rho, M.-C. Anti-inflammatory activity of eudesmane-type sesquiterpenoids from Salvia plebeia. J. Nat. Prod. 2017, 80, 2666-2676. [CrossRef]

23. Righi, N.; Boumerfeg, S.; Deghima, A.; Fernandes, P.A.; Coelho, E.; Baali, F.; Cardoso, S.M.; Coimbra, M.A.; Baghiani, A. Phenolic profile, safety assessment, and anti-inflammatory activity of Salvia verbenaca L. J. Ethnopharmacol. 2021, 272, 113940. [CrossRef]

24. Hafez Ghoran, S.; Firuzi, O.; Jassbi, A.R. Phytoconstituents from the Aerial Parts of Salvia dracocephaloides Boiss. and their Biological Activities. J. Environ. Treat. Tech. 2020, 8, 1274-1278. [CrossRef]

25. Rowshan, V.; Najafian, S. Polyphenolic contents and antioxidant activities of aerial parts of Salvia multicaulis from the Iran flora. Nat. Prod. Res. 2019, 34, 2351-2353. [CrossRef] [PubMed]

26. Gülçin, I.; Tel, A.Z.; Goren, A.C.; Taslimi, P.; Alwasel, S.H. Sage (Salvia pilifera): Determination of its polyphenol contents, anticholinergic, antidiabetic and antioxidant activities. J. Food Meas. Charact. 2019, 13, 2062-2074. [CrossRef]

27. Pereira, O.R.; Catarino, M.D.; Afonso, A.F.; Silva, A.M.S.; Cardoso, S.M. Salvia elegans, Salvia greggii and Salvia officinalis decoctions: Antioxidant activities and inhibition of carbohydrate and lipid metabolic enzymes. Molecules 2018, 23, 3169. [CrossRef]

28. Eltawaty, S.I.; Yagoub, S.O.; Shouman, S.A.; Ahmed, A.; Omer, F.A. Anticancer effects of methanol extract of Libyan Salvia fruticosa Mill on Mcf7, T47D and (Mda-Mb-468) breast cells lines. Eur. J. Pharm. Med. Res. 2020, 7, 165-169.

29. Balaei-Kahnamoei, M.; Eftekhari, M.; Ardekani, M.R.S.; Akbarzadeh, T.; Saeedi, M.; Jamalifar, H.; Safavi, M.; Sam, S.; Zhalehjoo, N.; Khanavi, M. Phytochemical constituents and biological activities of Salvia macrosiphon Boiss. BMC Chem. 2021, 15, 4. [CrossRef]

30. Eghbaliferiz, S.; Emami, S.A.; Tayarani-Najaran, Z.; Iranshahi, M.; Shakeri, A.; Hohmann, J.; Asili, J. Cytotoxic diterpene quinones from Salvia tebesana Bunge. Fitoterapia 2018, 128, 97-101. [CrossRef]

31. Shakeri, A.; Farahmand, S.S.; Tayarani-Najaran, Z.; Emami, S.A.; Kúsz, N.; Hohmann, J.; Boozari, M.; Tavallaie, F.Z.; Asili, J. 4,5-Seco-5,10-friedo-abietane-type diterpenoids with anticancer activity from Salvia atropatana Bunge. Naunyn-Schmiedebergs Archiv für Experimentelle Pathologie und Pharmakologie 2020, 394, 241-248. [CrossRef]

32. Bustos-Brito, C.; Joseph-Nathan, P.; Burgueño-Tapia, E.; Martínez-Otero, D.; Nieto-Camacho, A.; Calzada, F.; Yépez-Mulia, L.; Esquivel, B.; Quijano, L. Structure and absolute configuration of abietane diterpenoids from Salvia clinopodioides: Antioxidant, Antiprotozoal, and Antipropulsive Activities. J. Nat. Prod. 2019, 82, 1207-1216. [CrossRef]

33. Cezarotto, C.S.; Dorneles, A.; Baldissera, F.G.; da Silva, M.B.; Markoski, M.M.; Junior, L.R.; Peres, A.; Fazolo, T.; Bordignon, S.A.; Apel, M.A.; et al. Leishmanicidal and antichemotactic activities of icetexanes from Salvia uliginosa Benth. Phytomedicine 2018, 58, 152748. [CrossRef] [PubMed]

34. Kuźma, Ł.; Kaiser, M.; Wysokińska, H. The production and antiprotozoal activity of abietane diterpenes in Salvia austriaca hairy roots grown in shake flasks and bioreactor. Prep. Biochem. Biotechnol. 2016, 47, 58-66. [CrossRef] [PubMed]

35. Tabanca, N.; Demirci, B.; Baser, K.H.C.; Aytac, Z.; Ekici, M.; Khan, S.I.; Jacob, M.R.; Wedge, D.E. Chemical composition and antifungal activity of Salvia macrochlamys and Salvia recognita essential oils. J. Agric. Food Chem. 2006, 54, 6593-6597. [CrossRef] [PubMed]

36. Soković, M.D.; Brkić, D.D.; Džamić, A.M.; Ristić, M.S.; Marin, P.D. Chemical composition and antifungal activity of Salvia desoleana Atzei \& Picci essential oil and its major components. Flavour Fragr. J. 2009, 24, 83-87. [CrossRef]

37. Liang, Y.-Y.; Li, K.-W.; Niu, F.-J.; Li, Y.; Wei, H.-C.; Dai, Y.-L.; Wang, Y.-Y.; Zhou, C.-Z.; Wan, X.-H. Salvia plebeia R. Br. polysaccharides (SPP) against RSV (respiratory syncytial virus) infection: Antiviral effect and mechanisms of action. Biomed. Pharmacother. 2021, 141, 111843. [CrossRef] [PubMed]

38. Ustun, O.; Ozcelik, B. In vitro antiviral activity and cytotoxicity of the extracts of Salvia wiedemannii Boiss. Planta Med. 2011, 77, PL23. [CrossRef]

39. Azad, M.M.; Al Mahmud, A.; Islam, S.; Gouhar, A.I. Common sage (Salvia officinalis) antiviral role: Potentiality of a Unani hand sanitizer in COVID-19 (corona virus) second wave control. Asian J. Med Biol. Res. 2021, 6, 611-617. [CrossRef]

40. Najar, B.; Mecacci, G.; Nardi, V.; Cervelli, C.; Nardoni, S.; Mancianti, F.; Ebani, V.; Giannecchini, S.; Pistelli, L. Volatiles and antifungal-antibacterial-antiviral activity of South African Salvia spp. essential oils cultivated in uniform conditions. Molecules 2021, 26, 2826. [CrossRef]

41. Güzel, S.; Özay, Y.; Kumaş, M.; Uzun, C.; Özkorkmaz, E.G.; Yıldırım, Z.; Ülger, M.; Güler, G.; Çelik, A.; Çamlıca, Y.; et al. Wound healing properties, antimicrobial and antioxidant activities of Salvia kronenburgii Rech. f. and Salvia euphratica Montbret, Aucher \& Rech. f. var. euphratica on excision and incision wound models in diabetic rats. Biomed. Pharmacother. 2019, 111, 1260-1276. [CrossRef]

42. Bisio, A.; De Mieri, M.; Milella, L.; Schito, A.M.; Parricchi, A.; Russo, D.; Alfei, S.; Lapillo, M.; Tuccinardi, T.; Hamburger, M.; et al. Antibacterial and hypoglycemic diterpenoids from Salvia chamaedryoides. J. Nat. Prod. 2017, 80, 503-514. [CrossRef]

43. Jassbi, A.R.; Zare, S.; Firuzi, O.; Xiao, J. Bioactive phytochemicals from shoots and roots of Salvia species. Phytochem. Rev. 2015, 15, 829-867. [CrossRef] 
44. Xu, J.; Wei, K.; Zhang, G.; Lei, L.; Yang, D.; Wang, W.; Han, Q.; Xia, Y.; Bi, Y.; Yang, M.; et al. Ethnopharmacology, phytochemistry, and pharmacology of Chinese Salvia species: A review. J. Ethnopharmacol. 2018, 225, 18-30. [CrossRef]

45. Luis, J.G.; Lahlou, E.H.; Andrés, L.S.; Sood, G.H.; Ripoll, M.M. Apiananes: $C_{23}$ terpenoids with a new type of skeleton from Salvia apiana. Tetrahedron Lett. 1996, 37, 4213-4216. [CrossRef]

46. Luis, J.G.; Lahlou, E.H.; Andrés, L.S. Hassananes: $\mathrm{C}_{23}$ terpenoids with a new type of skeleton from Salvia apiana Jeps. Tetrahedron 1996, 52, 12309-12312. [CrossRef]

47. Miura, K.; Kikuzaki, H.; Nakatani, N. Apianane terpenoids from Salvia officinalis. Phytochemistry 2001, 58, 1171-1175. [CrossRef]

48. Xu, G.; Hou, A.-J.; Wang, R.-R.; Liang, G.-Y.; Zheng, Y.-T.; Liu, Z.-Y.; Li, X.-L.; Zhao, Y.; Huang, S.-X.; Peng, L.-Y.; et al. Przewalskin A: A new $\mathrm{C}_{23}$ terpenoid with a 6/6/7 carbon ring skeleton from Salvia przewalskii Maxim. Org. Lett. 2006, 8, 4453-4456. [CrossRef]

49. Wu, W.L.; Chang, W.L.; Chen, C.F. Cytotoxic activities of tanshinones against human carcinoma cell lines. Am. J. Chin. Med. 1991, 19, 207-216. [CrossRef]

50. Chen, Q.; Li, J.; Ma, Y.; Yuan, W.; Zhang, P.; Wang, G. Occurrence and biosynthesis of plant sesterterpenes (C25), a new addition to terpene diversity. Plant Commun. 2021, 2, 100184. [CrossRef]

51. Guo, K.; Liu, Y.; Li, S.H. The untapped potential of plant sesterterpenoids: Chemistry, biological activities and biosynthesis. Nat. Prod. Rep. 2021, 38, 2293-2314. [CrossRef]

52. Bisio, A.; Schito, A.M.; Pedrelli, F.; Danton, O.; Reinhardt, J.K.; Poli, G.; Tuccinardi, T.; Bürgi, T.; De Riccardis, F.; Giacomini, M.; et al. Antibacterial and ATP synthesis modulating compounds from Salvia tingitana. J. Nat. Prod. 2020, 83, 1027-1042. [CrossRef]

53. Cioffi, G.; Bader, A.; Malafronte, A.; Piaz, F.D.; De Tommasi, N. Secondary metabolites from the aerial parts of Salvia palaestina Bentham. Phytochemistry 2008, 69, 1005-1012. [CrossRef] [PubMed]

54. Piaz, F.D.; Vassallo, A.; Lepore, L.; Tosco, A.; Bader, A.; De Tommasi, N. Sesterterpenes as tubulin tyrosine ligase inhibitors. First insight of structure-activity relationships and discovery of new lead. J. Med. Chem. 2009, 52, 3814-3828. [CrossRef] [PubMed]

55. Rustaiyan, A.; Sadjadi, A. Salvisyriacolide, a sesterterpene from Salvia syriaca. Phytochemistry 1987, 26, 3078-3079. [CrossRef]

56. Piaz, F.D.; Imparato, S.; Lepore, L.; Bader, A.; De Tommasi, N. A fast and efficient LC-MS/MS method for detection, identification and quantitative analysis of bioactive sesterterpenes in Salvia dominica crude extracts. J. Pharm. Biomed. Anal. 2010, 51, 70-77. [CrossRef] [PubMed]

57. Moghaddam, F.M.; Amiri, R.; Alam, M.; Hossain, M.B.; van der Helm, D. Structure and absolute stereochemistry of salvimirzacolide, a new sesterterpene from Salvia mirzayanii. J. Nat. Prod. 1998, 61, 279-281. [CrossRef] [PubMed]

58. Rustaiyan, A.; Niknejad, A.; Nazarians, L.; Jakupovic, J.; Bohlmann, F. Sesterterpenes from Salvia hypoleuca. Phytochemistry 1982, 21, 1812-1813. [CrossRef]

59. Moghaddam, F.M.; Zaynizadeh, B.; Rüedi, P. Salvileucolide methylester, a sesterterpene from Salvia Sahendica. Phytochemistry 1995, 39, 715-716. [CrossRef]

60. Linden, A.; Juch, M.; Moghaddam, F.M.; Zaynizadeh, B.; Rüedi, P. The absolute configuration of salvileucolide methyl ester, a sesterterpene from Iranian Salvia species. Phytochemistry 1996, 41, 589-590. [CrossRef]

61. Rustaiyan, A.; Koussari, S. Further sesterterpenes from Salvia hypoleuca. Phytochemistry 1988, 27, 1767-1769. [CrossRef]

62. Farimani, M.M.; Mazarei, Z. Sesterterpenoids and other constituents from Salvia lachnocalyx Hedge. Fitoterapia 2014, 98, 234-240. [CrossRef]

63. Moghaddam, F.M.; Farimani, M.M.; Seirafi, M.; Taheri, S.; Khavasi, H.R.; Sendker, J.; Proksch, P.; Wray, V.; Edrada, R. Sesterterpenoids and other constituents of Salvia sahendica. J. Nat. Prod. 2010, 73, 1601-1605. [CrossRef]

64. Hasan, M.R.; Al-Jaber, H.I.; Al-Qudah, M.; Abu Zarga, M.H. New sesterterpenoids and other constituents from Salvia dominica growing wild in Jordan. Phytochem. Lett. 2016, 16, 12-17. [CrossRef]

65. Gonzalez, M.; Segundo, J.S.; Grande, M.; Medarde, M.; Bellido, I. Sesterterpene lactones from Salvia aethiopis. Salviaethiopisolide and 13-epi-salviaethiopisolide. Tetrahedron 1989, 45, 3575-3582. [CrossRef]

66. Topcu, G.; Ulubelen, A.; Tam, T.C.-M.; Tao-Che, C. Sesterterpenes and other constituents of Salvia yosgadensis. Phytochemistry 1996, 42, 1089-1092. [CrossRef]

67. Malafronte, A.; Piaz, F.D.; Cioffi, G.; Braca, A.; Leone, A.; De Tommasi, N. Secondary metabolites from the aerial parts of Salvia aethiopis L. Nat. Prod. Commun. 2008, 3. [CrossRef]

68. Ebrahimi, S.N.; Farimani, M.M.; Mirzania, F.; Soltanipoor, M.A.; De Mieri, M.; Hamburger, M. Manoyloxide sesterterpenoids from Salvia mirzayanii. J. Nat. Prod. 2014, 77, 848-854. [CrossRef]

69. Topcu, G.; Ulubelen, A.; Tam, T.C.M.; Che, C.T. Norditerpenes and norsesterterpenes from Salvia yosgadensis. J. Nat. Prod. 1996, 59, 113-116. [CrossRef]

70. Ulubelen, A.; Topcu, G.; Sönmez, U.; Eriş, C.; Özgen, U. Norsesterterpenes and diterpenes from the aerial parts of Salvia limbata. Phytochemistry 1996, 43, 431-434. [CrossRef]

71. Ruan, J.; Zheng, C.; Qu, L.; Liu, Y.; Han, L.; Yu, H.; Zhang, Y.; Wang, T. Plant resources, ${ }^{13}$ C-NMR spectral characteristic and pharmacological activities of dammarane-type triterpenoids. Molecules 2016, 21, 1047. [CrossRef]

72. Carradori, S.; Petzer, J.P. Novel monoamine oxidase inhibitors: A patent review (2012-2014). Expert Opin. Ther. Pat. 2015, 25, 91-110. [CrossRef]

73. Pedreros, S.; Rodríguez, B.; De La Torre, M.C.; Bruno, M.; Savona, G.; Perales, A.; Torres, M.R. Dammarane triterpenes of Salvia hierosolymitana. Phytochemistry 1990, 29, 919-922. [CrossRef] 
74. Kolak, U.; Kabouche, A.; Öztürk, M.; Kabouche, Z.; Topçu, G.; Ulubelen, A. Antioxidant diterpenoids from the roots of Salvia barrelieri. Phytochem. Anal. 2009, 20, 320-327. [CrossRef]

75. Yosioka, I.; Yamauchi, H.; Kitagawa, I. Lichen triterpenoids. V. On the neutral triterpenoids of Pyxine endochrysina NYL. Chem. Pharm. Bull. 1972, 20, 502-513. [CrossRef]

76. Valverde, S.; Escudero, J.; López, J.C.; Rabanal, R.M. Two terpenoids from Salvia bicolor. Phytochemistry 1985, $24,111-113$. [CrossRef]

77. Ahmad, Z.; Fatima, I.; Mehmood, S.; Ifzal, R.; Malik, A.; Afza, N. New epoxydammarane triterpenes from Salvia santolinifolia. Helvetica Chim. Acta 2008, 91, 73-78. [CrossRef]

78. Esquivel, B.; Guerrero, F.; Toscano, R. Tri-nordammarane triterpenoids and neoclerodane diterpenoids from Salvia aspera (Labiatae). Nat. Prod. Lett. 2002, 16, 129-135. [CrossRef] [PubMed]

79. Harraz, F.M.; Ulubelen, A.; Öksüz, S.; Tan, N. Dammarane triterpenes from Cleome amblyocarpa. Phytochemistry 1995, 39, 175-178. [CrossRef]

80. Ghoran, S.H.; Firuzi, O.; Asadollahi, M.; Stuppner, H.; Alilou, M.; Jassbi, A.R. Dammarane-type triterpenoid saponins from Salvia russellii Benth. Phytochemistry 2021, 184, 112653. [CrossRef]

81. Ahmad, V.U.; Zahid, M.; Ali, M.S.; Ali, Z.; Jassbi, A.R.; Abbas, M.; Clardy, J.; Lobkovsky, E.; Tareen, R.B.; Iqbal, M.Z. Salvadiones-A and -B: Two terpenoids having novel carbon skeleta from Salvia bucharica. J. Org. Chem. 1999, 64, 8465-8467. [CrossRef]

82. Ahmad, V.U.; Zahid, M.; Ali, M.S.; Choudhary, M.I.; Akhtar, F.; Ali, Z.; Iqbal, M.Z. Salvadiol: A novel triterpenoid from Salvia bucharica. Tetrahedron Lett. 1999, 40, 7561-7564. [CrossRef]

83. Farimani, M.M.; Bahadori, M.B.; Taheri, S.; Ebrahimi, S.N.; Zimmermann, S.; Brun, R.; Amin, G.; Hamburger, M. Triterpenoids with rare carbon skeletons from Salvia hydrangea: Antiprotozoal activity and absolute configurations. J. Nat. Prod. 2011, 74, 2200-2205. [CrossRef] [PubMed]

84. Farimani, M.M.; Taheri, S.; Ebrahimi, S.N.; Bahadori, M.B.; Khavasi, H.R.; Zimmermann, S.; Brun, R.; Hamburger, M. Hydrangenone, a new isoprenoid with an unprecedented skeleton from Salvia hydrangea. Org. Lett. 2011, 14, 166-169. [CrossRef] [PubMed]

85. Tabefam, M.; Farimani, M.M.; Danton, O.; Ramseyer, J.; Ebrahimi, S.N.; Neuburger, M.; Kaiser, M.; Salehi, P.; Potterat, O.; Hamburger, M. Antiprotozoal isoprenoids from Salvia hydrangea. J. Nat. Prod. 2018, 81, 2682-2691. [CrossRef] [PubMed]

86. Miura, K.; Kikuzaki, H.; Nakatani, N. Antioxidant activity of chemical components from sage (Salvia officinalis L.) and thyme (Thymus vulgaris L.) measured by the oil stability index method. J. Agric. Food Chem. 2002, 50, 1845-1851. [CrossRef]

87. Pais, G.C.G.; Zhang, X.; Marchand, C.; Neamati, N.; Cowansage, K.; Svarovskaia, E.S.; Pathak, V.K.; Tang, Y.; Nicklaus, M.; Pommier, Y.; et al. Structure activity of 3-aryl-1,3-diketo-containing compounds as HIV-1 integrase inhibitors. J. Med. Chem. 2002, 45, 3184-3194. [CrossRef] [PubMed] 